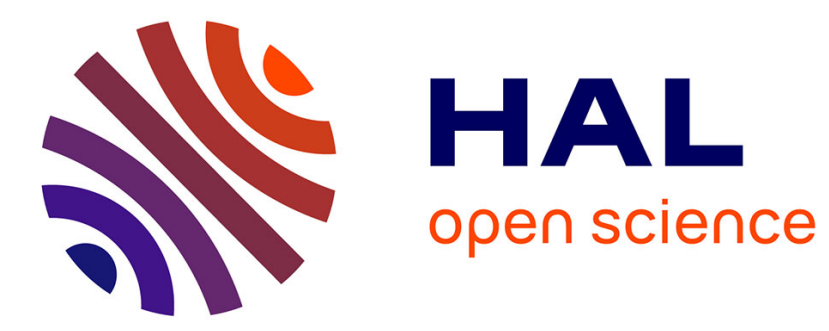

\title{
Flash flood modeling with the MARINE hydrological distributed model
}

\author{
V. Estupina-Borrell, Denis Dartus, Rachid Ababou
}

\section{To cite this version:}

V. Estupina-Borrell, Denis Dartus, Rachid Ababou. Flash flood modeling with the MARINE hydrological distributed model. Hydrology and Earth System Sciences Discussions, 2006, 3 (6), pp.3397-3438.

hal-00330793

\section{HAL Id: hal-00330793 \\ https://hal.science/hal-00330793}

Submitted on 3 Nov 2006

HAL is a multi-disciplinary open access archive for the deposit and dissemination of scientific research documents, whether they are published or not. The documents may come from teaching and research institutions in France or abroad, or from public or private research centers.
L'archive ouverte pluridisciplinaire HAL, est destinée au dépôt et à la diffusion de documents scientifiques de niveau recherche, publiés ou non, émanant des établissements d'enseignement et de recherche français ou étrangers, des laboratoires publics ou privés. 
Hydrol. Earth Syst. Sci. Discuss., 3, 3397-3438, 2006 www.hydrol-earth-syst-sci-discuss.net/3/3397/2006/

(C) Author(s) 2006. This work is licensed under a Creative Commons License.
Hydrology and Earth System Sciences Discussions

Papers published in Hydrology and Earth System Sciences Discussions are under open-access review for the journal Hydrology and Earth System Sciences

\section{Flash flood modeling with the MARINE hydrological distributed model}

\section{Estupina-Borrell, D. Dartus, and R. Ababou}

IMFT, Alle du Professeur Camille Soula, 31400 Toulouse, France

Received: 29 March 2006 - Accepted: 25 April 2006 - Published: 3 November 2006

Correspondence to: V. Estupina-Borrell(borrell@free.fr)

\section{HESSD}

3, 3397-3438, 2006

MARINE distributed model for flash flood modeling

V. Estupina-Borrell et al.

Title Page

Abstract

Introduction

Conclusions

References

Tables

Figures

14

I

4

Back

Close

Full Screen / Esc

Printer-friendly Version

Interactive Discussion 


\section{Abstract}

Flash floods are characterized by their violence and the rapidity of their occurrence. Because these events are rare and unpredictable, but also fast and intense, their anticipation with sufficient lead time for warning and broadcasting is a primary subject of 5 research. Because of the heterogeneities of the rain and of the behavior of the surface, spatially distributed hydrological models can lead to a better understanding of the processes and so on they can contribute to a better forecasting of flash flood. Our main goal here is to develop an operational and robust methodology for flash flood forecasting. This methodology should provide relevant data (information) about flood evolution on short time scales, and should be applicable even in locations where direct observations are sparse (e.g. absence of historical and modern rainfalls and streamflows in small mountainous watersheds). The flash flood forecast is obtained by the physically based, space-time distributed hydrological model "MARINE" (Model of Anticipation of Runoff and INondations for Extreme events). This model is presented and tested in this 15 paper for a real flash flood event. The model consists in two steps, or two components: the first component is a "basin" flood module which generates flood runoff in the upstream part of the watershed, and the second component is the "stream network" module, which propagates the flood in the main river and its subsidiaries. The basin flash flood generation model is a rainfall-runoff model that can integrate remotely sensed 20 data. Surface hydraulics equations are solved with enough simplifying hypotheses to allow real time exploitation. The minimum data required by the model are: (i) the Digital Elevation Model, used to calculate slopes that generate runoff, it can be issued from satellite imagery (SPOT) or from French Geographical Institute (IGN); (ii) the rainfall data from meteorological radar, observed or anticipated by the French Meteorological 25 Service (Météo France); and (iii) the spatially distributed soil and other surface properties viewed from space (land cover map from SPOT or LANDSAT, main rivers, ... ). The stream flood propagation model simulates flood propagation in main rivers by solving 1D Saint Venant equations. The data required for this part of the model are the river
HESSD

3, 3397-3438, 2006

\section{MARINE distributed model for flash flood modeling}

V. Estupina-Borrell et al.

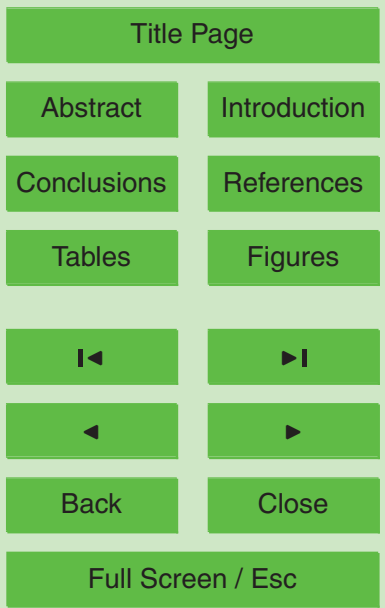

Printer-friendly Version

Interactive Discussion 
morphology, topography and roughness. The MARINE model has already been used previously for real time flash floods forecasting in the frame of the PACTES project on "forecasting and anticipation of floods with spatial techniques" (funded by the CNES and the French Ministry of Research) concerning the catastrophic 1999 flash flood that 5 occurred in the South of France. The main advantages of MARINE are its ability to run on insufficiently gauged basins (with the help of satellite information) and to run in an operational mode for real-time flood forecasting.

\section{Introduction}

Flash floods can be characterized as floods with a sudden and fast rise of stream flow, 10 and a large peak flow in terms of specific discharge rate (liters $/ \mathrm{s} / \mathrm{km}^{2}$ ). Flash floods are linked to intense storm events and occur on small areas (cf. IAHS et al., 1974). Their socio-economic consequences are important, and their anticipation is an acute technical problem, of great socio-economic consequences, as demonstrated by the catastrophic flash flood of November 1999 in southern France. Consider for this flash 15 flood example (see application section further below), the storm lasted 2 days, the maximum estimated rainfall intensity was $552 \mathrm{~mm} / 24 \mathrm{~h}$ at Lézignan Corbières (usually 700 to $800 \mathrm{~mm} /$ year are observed), the rising of the Orbieu river level reached $4.7 \mathrm{~m}$ in $4 \mathrm{~h}$ and the resulting peak discharge rate was estimated at $3000 \mathrm{~m}^{3} / \mathrm{s}$ at Moussoulens on the Aude river $\left(43 \mathrm{~m}^{3} / \mathrm{s}\right.$ for the mean annual value in this region). The scientific 20 study of these particular floods progresses slowly due to their complexity and their poor reliable observations, and the State services responsible for their assessment do not have tools performing enough for anticipation of these very particular floods.

Hydrologic models (based hydraulics) can be of precious help for analyzing and, most importantly, forecasting flash floods. The modeling approach is not unique, and 25 different model equations and solution methods are suggested in the literature. However, most models are not necessary compatible with real time forecasting requirements. Furthermore, the lack of accurate data characterizing flash floods is probably

\section{HESSD}

3, 3397-3438, 2006

\section{MARINE distributed model for flash flood modeling}

V. Estupina-Borrell et al.

Title Page

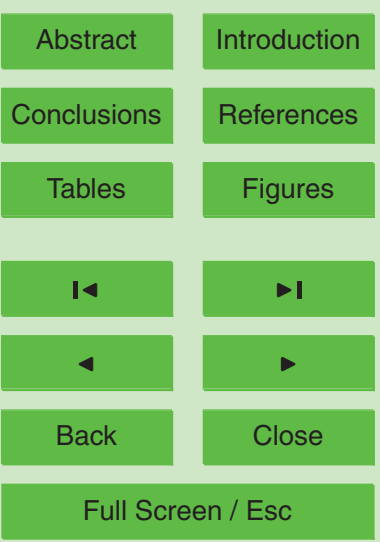

Printer-friendly Version

Interactive Discussion 
the major reason why their study is so delicate, and the validation of the models so difficult to achieve.

HESSD

\subsection{Flash flood processes}

Flash flood processes to be considered in our model are space-time distributed rainfall, flood production and propagation on heterogeneous sloping terrains (watersheds, basins), and flood propagation in rivers and their tributaries (stream networks).

For flash floods that occurred in southern France, the meteorological events that produced them are meso scale convective systems with a V-shaped pattern. Such systems produce high intensity rainfall, and they can yield very large volumes of precipitations on a (fixed) region of space, particularly when they are quasi-stationary.

Datin (1998) or Cosandey et al. (2000) observe that the correct "spatialisation" of rainfall can be of great importance. Here, "spatialisation" stands for spatial estimation of rainfall, e.g. interpolation and/or extrapolation, possibly followed by aggregation at the desired mesh scales. Ground radar measurement of rainfall is the only type of observation giving access to the space (and time) variability of such convective meteorological events. The resolution of the rainfall radar is typically $\triangle x R A D A R=1 \mathrm{~km}$ in space (for a snapshot map) and $\triangle \mathrm{tRADAR}=6 \mathrm{~min}$ in time (at any fixed point $\times 0$ ). Therefore, radar data may be an essential requirement for space-time rainfall estimation as input to flash flood simulation and forecasting models, particularly on (otherwise) ungauged basins. But this data is not always available, even in France, when dealing with past events.

The production of runoff in such intense storm events is an open subject. It seems that both excess saturation and excess infiltration overland flow can be involved in the mechanisms of the flash flood according to Albergel (2003). In general, both phe-
3, 3397-3438, 2006

\section{MARINE distributed model for flash flood modeling}

V. Estupina-Borrell et al.

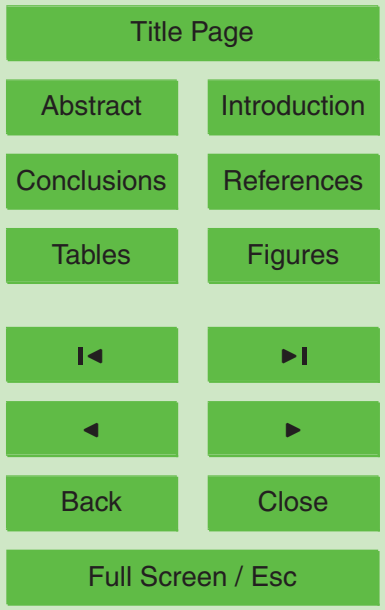

Printer-friendly Version

Interactive Discussion and other conditions, infiltration in a coupled saturated-unsaturated system can lead to a process where the descending infiltration front meets the ascending water table, with 
a transient perched water body in between. In spite of this complexity, it seems that basin behavior during a flood will mainly match one of the two afore-mentioned phenomena. Specifically, the climate, the soil properties and the qualitative observations of flash floods in southern France (described by Bousquet, 1997) let believe that the 5 "hortonian" runoff generation will be more appropriate for these types of flash floods.

Once, overland water has accumulated (pounded), it will run off over hill slopes: this process requires a spatially distributed (2-D) watershed/hill slope flood propagation model. In the physically based hydrological model TOPAKI proposed by Liu et al. (2002), run off is modeled in pseudo 2-D based on the cinematic wave approxima10 tion and assuming a constant water depth over the spatial unit of the model (supposed homogeneous mesh size). Its model supplies interesting results, so we are going to use this same run off model in the rest of the paper.

Furthermore the contribution of the underground water is neglected during these short and violent events.

Finally, evapotranspiration (ET) is approximated as a constant rate uptake of water during each storm/flood event. This is justified by the relatively short duration of a typical flash flood (less than 2 days) and the relatively slow nature of ET uptake (particularly during a storm). Penman's formula is used to estimate ET with event-averaged variables (temperatures, wind speed, etc.). Similarly, interception of rainfall by plants is approximated as a constant rate during each event.

\subsection{Review of some relevant flash flood models}

The rareness of flash flood events makes the statistical analysis and the calibration of deterministic hydrological models difficult. Montz et al. (2002) asserts that, because of the complexity of the processes involved in flash flood generation and propagation, the
HESSD

3, 3397-3438, 2006

\section{MARINE distributed model for flash flood modeling}

V. Estupina-Borrell et al.

Title Page

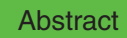

Introduction

Conclusions

Tables

References

Figures

14

$>$ I

4

Back

Close

Full Screen / Esc

Printer-friendly Version

Interactive Discussion approach. To model the previously described flood processes, many different solutions have been proposed in the literature. We only review here a selection of those approaches that seem most relevant to our objectives (real time flash flood forecasting). 
Foody et al. (2004) presents flash flood predictions using a semi-distributed model with the empirical SCS concept on the hill slopes, and a Muskingum scheme (reservoir type model) in the river. His model is driven from limited data, its key parameters are derived from topographic conventional data, field surveys, and land cover maps. Vieux 5 et al. (2004) prefers, for flood forecasting, a distributed model with the cinematic wave for runoff over hill slopes and Green and Ampt model for the infiltration, a channel routing model is added. Chahinian et al. (2005), for Mediterranean flood more or less strong, builds a framework of models offering different methods of conceptualization for the infiltration process: Green and Ampt, Horton, Philip, SCS. Gaume et al. (2004) 10 uses SCS concept for the simulation of the same flash flood as the one studied here. The results are quite interesting, but the value of the curve number needs a calibration, forbidding its use in real time forecasting without any more flash floods observations.

Because processes involved in flash flood phenomenon are very numerous and complex, Estupina-Borrell (2004) suggests to use the notion of model framework including 5 different conceptualizations for each process involved in the flash floods generation and propagation. Each model can be a simplified hydrological physically based model taking into account the spatial variability of the different processes involved (including the rain) and the runoff process over hillslopes is supposed to be derived from the cinematic wave approximation. The build model name is MARINE for Model of Anticipation of Runoff and INondations for Extrem events.

It is now recognized that data resolution can have strong influence on simulation results obtained with distributed model. The numerical solution conditions only guaranty stability and convergence. A specific analyze of the spatial variability of the most sensible data field is necessary to be sure that the process model takes into account the 25 appropriate data scale.

The main objective of this paper is to bring some elements of reflection on flash floods: the main processes involved in their generation and in their propagation, the way to model them and particularly to forecast them. It also focuses on the input data scale of distributed hydrologic model required to correctly traduce the spatial variability
HESSD

3, 3397-3438, 2006

\section{MARINE distributed model for flash flood modeling}

V. Estupina-Borrell et al.

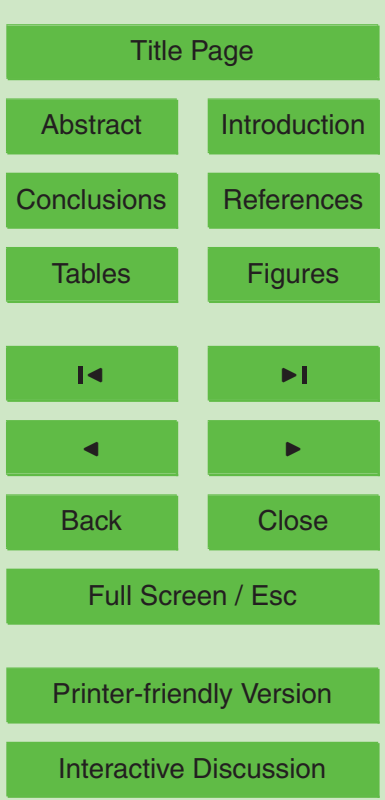

EGU 
of observations fields and to respect the field of validity of the model equations.

This paper is structured as follows. First provides a detailed presentation of the distributed hydrologic model build and used to predict some flash floods. The particular flash flood of November 1999 on the Orbieu basin upstream from Lagrasse (in 5 the southern France) is then described. Following the details of the calibration of the model, the results obtained are developed and discussed. They are also compared with previous studies available in the literature. The main conclusions concerning this kind of hydrologic model and their ability to help in the decision support system of flash flood forecasting are developed.

\section{General description of the MARINE model}

\subsection{MARINE structure}

MARINE is a distributed hydrological physically based model for flash floods forecast. It's general flow-chart is presented on Fig. 1 and detailed by Estupina-Borrell (2004) and Estupina-Borrell et al. (2005).

MARINE is composed of two different modules. The first one describes the overland flow (hydrologic watershed module) and the second one describes the flood propagation in the river (hydraulic stream flow module).

The first one module is a rainfall-runoff model which offers different ways to model the surface runoff and the infiltration. The surface runoff can be model:

20 - with a direct resolution of the cinematic wave equation (eulerian resolution)

- or with the variable isochrones concept (lagrangian resolution)

The infiltration can be modeled (see paragraphs just below):

- with a constant rate of infiltration scheme,
HESSD

3, 3397-3438, 2006

MARINE distributed model for flash flood modeling

V. Estupina-Borrell et al.

Title Page

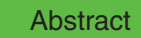

Introduction

Conclusions

References

Tables

Figures

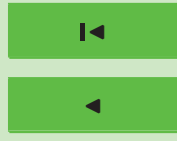

$\rightarrow 1$

Back

Close

Printer-friendly Version

Interactive Discussion 
- or with the Hortonian concept,

- or with Green and Ampt model.

HESSD

3, 3397-3438, 2006

At less, the necessary data are the Digital Elevation Model (DEM), the landcover map and the main river location and description. The real time data are the rainfall water 5 depth (calculated from the radar images by the atmospheric only models developed by Météo France). All these data can be remote sensed ones.

Some physically based parameters are derived from measurements (pedology, Strickler coefficient of the river, cross section of the main river...), some of them can also be adjusted with calibration on past events (hydraulic conductivity). This is also the methodology used for the estimation of the initial water content of the ground (volumetric soil water content) which is linked to the potential infiltrated volume of water.

This first overland flow module supplies flood hydrographs of the effective tributaries of the main river from the hill slopes. It constitutes the input of the following module.

The second one module, which describes the flood propagation in the river, solves the Saint Venant 1-D equations using standard code series such as MAGE (CEMAGREF) proposed by Giraud et al. (1997) or HEC-RAS (US Army Corps of Engineers). At least, the necessary data is a representation of the minor and medium beds of the river (longitudinal profile, cross sections, roughness). It supplies floods hydrographs all along the main river and in particular at the outlet of the basin. This 1-D module can be replaced by a 2-D river/floodplain module; however, we chose to use solely the above-described 1-D module for the real time flash flood simulations presented in this paper.

Real time forecasting on flash floods imposes to realize a compromise between the complexities of the physical processes involved, the poor available data and the little lead time for calculation before warning. Since for the floods of interest the surface runoff is the dominating process and, in front of their rapidity and of the volume of water they carry, we do not compute the following phenomenon: evapotranspiration is considered as constant over the event duration and is estimated with the Penman

\section{MARINE distributed model for flash flood modeling}

V. Estupina-Borrell et al.

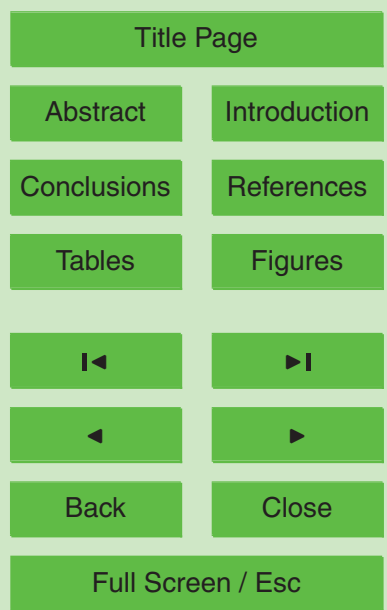

Printer-friendly Version

Interactive Discussion 
formula. It is traduced, with interception, through a less than $5 \%$ uncertainty over the value of the rainfall. Furthermore, lateral under ground transfers are characterized by transfer times which are not of the same scale order than those of flash flood processes for the basins of interest.

\section{$5 \quad 2.2$ DEM treatments}

The DEM is the data which supplies the information on water trajectories over the surface. This data should be able to determine the position of the permanent and temporary tributaries of the main river of the basin. Like all DEMs, it contains holes and peaks. The DEM treatment of MARINE proposed by Estupina et al. (2004) consists techniques. The determination of the optimal water paths is done from the original DEM, finding the steepest descent on an increasing neighborhood. According to the runoff resolution (eulerian or lagrangian) two different techniques are activated: either considering the whole neighborhood or only the four cardinal directions. The slopes are automatically corrected and the watershed delineation is obtained.

The data scales definitions have consequences on the quality of the information supplied by the DEM. If resolution and so on accuracy of the original DEM is too coarse, then the DEM may not still contain the information needed for hydrological applications.

\subsection{Relevant scales in the MARINE model}

20 A perceptual model (focused on the main physical processes) can not pretend to aggregate from very local information to large and global scale. Some scale thresholds have to be defined to fix a reasonable upscaling. Knowing the desired "outscale" of the model (the scale for which the model should supply flood hydrograph), the difficulty consists on defining the appropriate scales of the local processes, in relation to their 25 descriptive data (measurements).

Estupina-Borrell (2004) studies the validity field of runoff equation and shows that

\section{HESSD}

3, 3397-3438, 2006

\section{MARINE distributed model for flash flood modeling}

V. Estupina-Borrell et al.

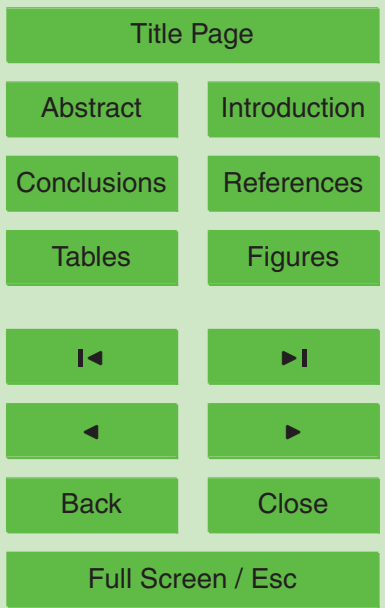

Printer-friendly Version

Interactive Discussion 
a limited upscaling is allowed. Then, the analyze of the equations validity leads to a first order of magnitude of the input pixel size. Furthermore, Sivapalan et al. (1998) and Rodriguez-Iturbe et al. (1974) show that the analyze of the distributed data correlogram leads to the definition of a second order of magnitude of the maximal data pixel size, above which the natural variability of the data risks not to be captured.

These two complementary analyzes, completed with a bibliographic review (Borgniet et al., 2003; Puech, 2000; Booij, 2002; Walsh et al., 2001; Meentemeyer, 1989) leads to an estimation of the input pixel scale of MARINE. The acquisition of the data will preferably have this resolution, if this resolution is not available, some sensitivity studies 10 will have to be done. Each equation is integrated on the pixel size of the model under homogeneous consideration.

\subsection{Basin-Stream decomposition of computational domain}

For purposes of computational efficiency, there is a need to distinguish, inside the watershed, two sub-domains: the "basin" or "hill slopes" where the 2-D hydrological watershed module of MARINE can be used, and the rivers or streams where the hydraulic stream flow module can be used. This decomposition is performed as a pre-processing of terrain data, taking into account the range of validity of the cinematic wave approximation used in the watershed module, as explained below.

According to Moore et al. (1990), the runoff over a basin can be approximated by 20 the cinematic wave approximation since the following non dimensional numbers are important enough:

$k=(I . L) /\left(F_{L}^{2} \cdot h_{L}\right)>10$

I.L $/ h_{L}>5$

where $/$ is the slope, $L$ is the length of the slope, $h_{L}$ is the water height at the bottom of

HESSD

3, 3397-3438, 2006

\section{MARINE distributed model for flash flood modeling}

V. Estupina-Borrell et al.

Title Page

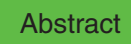

Introduction

Conclusions

Tables

References

Figures

14

4

Back

Close

Full Screen / Esc

Printer-friendly Version

Interactive Discussion 
the hill slopes and $F_{L}$ is the Froude number:

$F_{L}=u_{L} / \sqrt{g h_{L}}$

HESSD

where $u_{L}$ is the water velocity down hill slopes $(\mathrm{m} / \mathrm{s}), \mathrm{g}$ is the value of the acceleration of gravity $\left(\mathrm{m} / \mathrm{s}^{2}\right)$ and $h_{L}$ is the water height at the bottom of the hill slopes $(\mathrm{m})$.

"k" represents the number of cinematic flow. If its value is strong enough, than the cinematic wave equation is a good approximation of the flow behaviour (Fig. 2). Furthermore, Moore et al. (1990) shows that it is a good approximation when lateral flows are important compared with the total amount flow.

These dimensionless numbers are calculated a priori using the spatially distributed characteristics of the basin (topography and land cover parameters) and the characteristics of the rain (very important for flash flood). The range of validity of the cinematic wave approximation excludes a sub-domain of the basin where runoff processes have to be conceptualized with a less stringent approximation. It turns out that the latter sub-domain, computed from spatially distributed " $k$ " and " $F$ " parameters, matches with the main stream network of the basin for the major part (as observed from classical aerial photo maps and post analysis crisis studies). This computed stream network is used as the sub-domain for solving the Saint Venant equations (second module of MARINE). Overall, when considering the complete domain, the "basin" sub-domain, tends to be located upstream, and the stream network sub-domain is downstream.

\section{Hydraulic flood propagation equations}

According to the previous discussion, we distinguish in the Marine model two types of flood hydraulics: watershed hydraulics (hillslopes), and stream hydraulics.

\section{MARINE distributed model for flash flood modeling}

V. Estupina-Borrell et al.

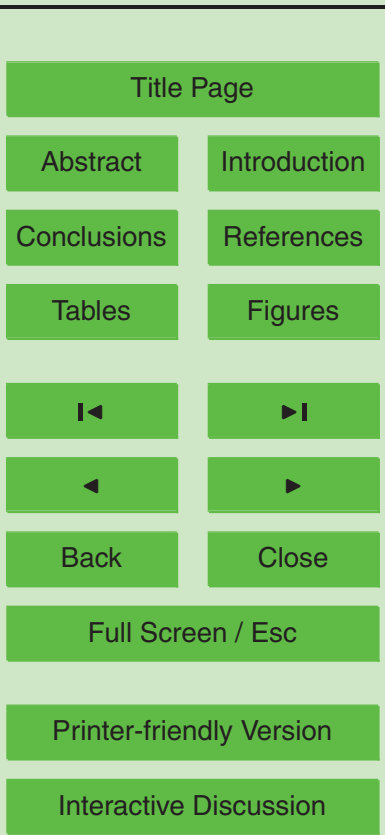




\subsection{Water balance (watershed module)}

The reduced water balance expressed in water height is given by:

$$
P(t)-F(t)=R(t)
$$

where $P(t)$ is the rainfall height $(\mathrm{mm}), F(t)$ is the cumulated infiltrated water height, and $5 R(t)$ is the surface water height available for surface runoff. All quantities here are cumulated over a time step. The rainfall is given by the radar imagery or the rain gauges. Note that the rainfall rate $i P=d P / d t$ can be approximated here as $i P(t)=P(t) / \Delta t$.

\subsection{Infiltration equations (watershed module)}

In MARINE, 3 different infiltration models exist in the infiltration module. Each of them calculate the value of the cumulated infiltrated water height $F(t)$ during the flood. The choice of the infiltration model to run in an application is more often imposes by the available data. These models are the following ones.

The constant infiltration rate described by Mallants et al. (1990) is indicated from the knowledge of the slope, the landcover and the pedology.

15 The Hortonian model proposed by Horton (1940) has 3 parameters. The infiltration velocity of the water inside the soil decreases as the event progresses, it is described by:

$f_{p}(t)=f_{c}+\left(f_{0}-f_{c}\right) \cdot e^{-\beta \cdot t}$

where $f_{p}$ is the infiltration capacity of the soil, $f_{c}$ is the hydraulic conductivity at saturation, $f_{0}$ is the maximal value of the infiltrability at the beginning of the event, $\beta$ is a positive constant and the time from the beginning of the event. If the rainfall intensity is stronger than the infiltration capacity, then runoff appears on the surface of the soil. Its integral form between the beginning of the event and the current time is:

$$
F(t)=f_{c} \cdot t+\left(f_{0}-f_{c}\right) \cdot\left(1-e^{-\beta \cdot t}\right) / \beta
$$

HESSD

3, 3397-3438, 2006

\section{MARINE distributed model for flash flood modeling}

V. Estupina-Borrell et al.

Title Page

Abstract Introduction

Conclusions References

Tables Figures

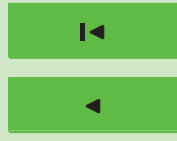

$\rightarrow 1$

Back

Close

Full Screen / Esc

Printer-friendly Version

Interactive Discussion 
where $F(t)$ is the cumulated water height infiltrated. If the rainfall rate is smaller than the infiltration capacity (rate), then this infiltrated water height should be numerically corrected with the introduction of an artificial equivalent time. The resolution of this equation in MARINE is upstream time explicit.

5 In the Green and Ampt model, once the pounding time has been reached, the infiltration capacity (rate) is modeled by:

$f_{p}(t)=K \cdot\left[1+\frac{\left(\theta_{s}-\theta_{i}\right) \cdot S_{f}}{F(t)}\right]$

where $K$ is the hydraulic conductivity, $S_{f}$ is the wetting front suction, $\theta_{S}$ is the saturated water content or porosity of the soil (also denoted $\Phi$ ), $\theta_{i}$ the initial water content, and $F$ the total water height infiltrated. The resolution of this equation in MARINE is upstream time explicit if the pounding time is neglected and implicit in the case of pounding process.

\subsection{Runoff equations (watershed module)}

Once the runoff water height is evaluated $(R(t))$, it is transferred all over the hill slopes, 15 with one of the two proposed rooting methods presented bellow.

The first one method consists on a direct resolution of the cinematic wave approximation. The water is supposed to be uniformly distributed over a pixel and its local velocity $(U)$ is approached by:

$|U|=\frac{h_{n}^{\frac{2}{3}}}{n} \cdot \sqrt{|/|}$

20 Where $U$ is the velocity $(\mathrm{m} / \mathrm{s}), n$ is the Manning coefficient $\left(\mathrm{m}^{-1 / 3} . \mathrm{s}\right)$, hn is the uniform water height on the soil $(\mathrm{m})$ and $\mathrm{I}$ is the local slope of the hill slope $(\mathrm{m} / \mathrm{m})$.

The resolution is realized with an eulerian approach solving the mass balance for each pixel of the model discretised over the grid of the DEM with an explicit upstream

\section{HESSD}

3, 3397-3438, 2006

\section{MARINE distributed model for flash flood modeling}

V. Estupina-Borrell et al.

Title Page

Abstract

Introduction

Conclusions

References

Tables

Figures

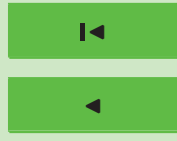

$\rightarrow$

Back

Close

Printer-friendly Version

Interactive Discussion 
scheme:

$\Delta m_{i}+\sum_{j=1,4} v_{j} \cdot n_{j} \frac{m_{j}}{d x} \Delta t=R(t) \times d x^{2}$

HESSD

where $i$ is the current pixel and $j$ one of the 4 adjacent pixels, $d x$ is the scale of the pixel and $n$ is the outside direction of the pixel side. Recall that $R(t)$ is the water height 5 ave available for runoff, accumulated over a time step $\Delta t$, as defined in Eq. (3).

The second way of estimating surface runoff (in our model) is by using the concept of variable isochrones (see Fig. 3).

The solution method is lagrangian, considering each one of the pixels of the DEM grid.

10 Classically the hypothesis of the isochrones and unit hydrograph concepts are uniform rain, global behavior of the basin and linear rainfall-runoff relation. In the methodology developed here, some of them have been relaxed: heterogeneities of rain can be taken into account, heterogeneities of the topography and land cover are considered and rainfall-runoff relation is based on cinematic wave velocity. Considering the most complete resolution, the water depth over each pixel should be calculated at each time step, but the estimation of this last value is too much time consuming in calculation for real time conditions. The optimal solution adopted here consists on making a balance at the pixel scale to evaluate an equivalent potential local water depth (Fig. 4 and Eq. 9).

$h_{20}=\left(\frac{I_{P i j} \cdot S_{s s b v i j} \cdot n_{i j}}{\sqrt{I_{i j}} \cdot I_{i j}}\right)^{\frac{3}{5}}$

where $h_{i j}$ is the equivalent potential water depth on the pixel, $I_{P i j}$ is the rain intensity, $S_{s s b v i j}$ is the area of the sub-basin upstream the pixel, $n_{i j}$ is the Manning coefficient, $I_{i j}$ is the local slope and $I_{i j}$ is the stream flow width. This expression is used in the

\section{MARINE distributed model for flash flood modeling}

V. Estupina-Borrell et al.

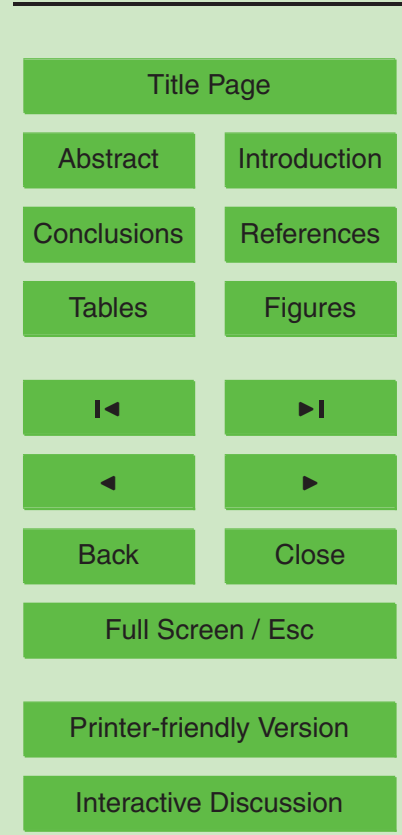

EGU 
evaluation of the cinematic wave velocity with the real time estimation of the rainfall supplied by Meteo France through the warning bulletins. The 8 adjacent pixels are considered to determine the maximum steepest direction of the flow.

The calibration of the isochrones is derived from the concentration time formula of 5 Henderson et al. (1964):

$T_{e}=i_{P}^{-\frac{2}{5}} \cdot L^{\frac{3}{5}} \cdot I^{-\frac{3}{10}} \cdot n^{\frac{3}{5}}$

where $T_{e}$ is the equilibrium time of the basin (s), $i_{p}$ is the rain intensity $(\mathrm{m} / \mathrm{s}), L$ is the length $(\mathrm{m}), l$ is the slope $(\mathrm{m} / \mathrm{m}), n$ is the Manning coefficient $\left(\mathrm{m}^{-\frac{1}{3}} \cdot \mathrm{s}\right)$. Following the same idea than above, to introduce heterogeneity in the pixel water depth, the formula becomes:

$T_{\text {isochrone }}=\sum_{\text {pathway }} i_{P}^{-\frac{2}{5}} \cdot I_{i j}^{-\frac{3}{10}} \cdot n_{i j}^{\frac{3}{5}} \cdot S_{s s b v i j}^{\frac{3}{5}} \cdot$ pas $^{-\frac{3}{5}}$

where $T_{\text {isochrone }}$ is the equilibrium time of a given isochrone line, $S_{\text {ssbvij }}$ is the area of the sub-basin upstream the pixel and pas is the horizontal resolution of the pixel.

Then, considering the rain occurred at 11 time over the basin, its contribution to the outlet flow at $\mathrm{t} 2$ temps is calculated by the convolution product between the Time Area graph and the rainfall supplies the flood hydrograph:

$d Q\left(t_{2}\right)=I_{P n}\left(t_{1}\right) \times d A\left(t_{2}-t_{1}\right)$

where $d Q$ is a fraction of the outlet flow caused by surface runoff, $I_{P n}$ is the net rain intensity, $d A$ is the part of the area watershed between two isochrone lines.

20 The integration of these elementary contributions supplies the outlet runoff flood hydrograph, which can be expressed on its distributed form by:

$Q_{j}=\sum_{k=1}^{j} I_{P n k} \times A_{j-k+1}$

HESSD

3, 3397-3438, 2006

MARINE distributed model for flash flood modeling

V. Estupina-Borrell et al.

Title Page

Abstract

Introduction

Conclusions

References

Tables

Figures

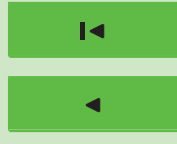

$\rightarrow$

Back

Close

Printer-friendly Version

Interactive Discussion 
where $Q_{j}$ is the outlet flow at time $j$ (coinciding with $t_{2}$ ), $I_{p n}$ is the net rain intensity, $A$ is the watershed area between isochrone $(j-k+1)$ and isochrone $(j-k)$.

The use of the concept of variable isochrones, instead of the direct resolution of the cinematic wave approximation, leads us to consider that the infiltration is effective only 5 at the rainfall location, and as a consequence, it leads us to neglect "re-infiltration" phenomena. According to Moore et al. (1990) and Carluer (1998), this approximation can lead to an error of at most $10 \%$ on the rising curve of the flash flood hydrograph.

In both cases (concept of variable isochrones and direct resolution of the cinematic wave approximation), the 2-D basin runoff module supplies important flow data for the 10 pixels that are outlets to the stream network, e.g. pixels coinciding with the outlet of temporary or permanent tributaries to the main river.

\subsection{River propagation equations (stream network module)}

The propagation inside the river is performed by solving the complete Saint Venant equations, which can be expressed as follow (taking into account a lateral input flow in the continuity equation):

$$
\begin{aligned}
& \frac{\partial S}{\partial t}+\frac{\partial Q}{\partial x}=q_{\text {lat }} \\
& \frac{\partial Q}{\partial t}+\frac{\partial\left(Q^{2} / S\right)}{\partial x}+g S \frac{\partial H}{\partial x}=g S(I-J)+k q_{\text {lat }} \frac{Q}{S}
\end{aligned}
$$

where $S$ is the cross section of the river, $q_{\text {lat }}$ is the lateral flow from the tributaries of the main river (output of the hydrologic watershed module), supplied by the watershed module of MARINE, $x$ is the coordinate along the river, $Q$ is the river flow, the time, $H$ the water height of the river, $/$ its topographic slope and $J$ is energy slope.

The solution of these equations is performed by the MAGE 1-D code (CEMAGREF software, presented by Guiraudet al., 1997).

\section{HESSD}

3, 3397-3438, 2006

\section{MARINE distributed model for flash flood modeling}

V. Estupina-Borrell et al.

Title Page

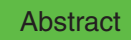

Introduction

Conclusions

Tables

References

Figures

14

4

Back

Close

\section{Full Screen / Esc}

Printer-friendly Version

Interactive Discussion 


\section{Application and test of the model: the 1999 flash flood at Lagrasse (Aude, France)}

MARINE has been tested for the flash flood of the Orbieu river basin on the 12 and 13 of November 1999. The area of the basin is about $250 \mathrm{~km}^{2}$ upstream from Lagrasse

5 village. The sub-basin of interest (Orbieu) is part of the mediterranean Aude basin $\left(4840 \mathrm{~km}^{2}\right)$ in southern France. The Orbieu river is the main tributary of the Aude river, it drains the northern part of the Corbières mountains. Fore more detailed information on this flash flood, the reader is referred to Gaume et al. (2004).

\subsection{Basin description and data}

10 The Digital Elevation Model (DEM) is extracted from the BD IGN with a spatial resolution of $50 \mathrm{~m}$ (Fig. 5) and the land cover map is interpreted from a LANDSAT TM image (Fig. 6). The soil is mainly sandy clay loam.

For this event, we have the data of three rain gauges located inside the basin (Fig. 7). The Thiessen repartition of the rain gauges was implemented. Maximal rainfall inten15 sity is $60 \mathrm{~mm} / \mathrm{h}$, its duration is about 1.5 days and the cumulative rain on the basin is between 300 and $400 \mathrm{~mm}$ (Fig. 8). The cumulated rainfall observed with the meteorological radar gives more information about the rainfall location (Fig. 9).

The river water elevation observed gives information on the flows that occurred at Lagrasse (Fig. 10), but this indication is full of uncertainties because of the necessary 20 extrapolation of the stage discharge relationship and of the observations themselves (sediments, debris and instrumentation).

\subsection{Optimal resolution of distributed (rainfall and DEM) data}

In this section, we analyze the best possible choices concerning the resolution of distributed space(-time) data, along with the chosen decomposition between the "basin" and "stream network" sub-domains. The spatially distributed data differ from the more

HESSD

3, 3397-3438, 2006

\section{MARINE distributed model for flash flood modeling}

V. Estupina-Borrell et al.

Title Page

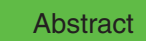

Introduction

Conclusions

References

Tables

Figures

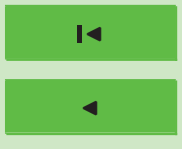

$\rightarrow 1$

Back

Close

Full Screen / Esc

Printer-friendly Version

Interactive Discussion 
classical hydrologic observations (and from the needed inputs of the hydrological equations) in theme, spatial and temporal resolutions and in precision. That's why a specific work has to be done concerning the resolution of the distributed field of data and the process to model.

5 Sensitivity tests realized on different DEM resolutions ( $\triangle \mathrm{xDEM})$ show that the maximal resolution of DEM for hydrological applications with MARINE on the Orbieu basin is about $100 \mathrm{~m}$ (above this threshold, the precision of the information is not fine enough to determine faithful runoff pathways).

The autocorrelogram study of the available DEM (the autocorrelation function sup10 plies a common approach to investigating the effect of a nonlinear scalar transformation on a strongly stationary time series by representing the dependence between a pair of variables) confirms the hypothesis that a resolution between $100 \mathrm{~m}$ and $150 \mathrm{~m}$ could be enough (Fig. 11).

The minimal distributed data resolution is not defined by these methodologies, but 15 the equations used to characterize processes (cinematic wave approximation in this case) is validate for a maximum step between the input data resolution and the basin scale. Choosing very precise data will conduce to define a sub-model to treat them.

To conclude this part, for the watershed under study, the input pixel scale of MARINE is evaluated by 2 different methodologies and comforted by the literature between a few ten meters to about hundred meters. Since the available data have a $50 \mathrm{~m}$ resolution, this pixel size will be used for the study (the detailed study dealing with horizontal resolution and vertical accuracy is presented in Estupina-Borrell (2004).

The decomposition between the two modules of MARINE (hydrological runoff on hill slopes, and hydraulic flood propagation in the rivers) were defined by applying criteria to the spatially distributed dimensionless numbers " $F$ " and " $k$ " presented earlier (Eqs. 1 and 2). In the specific case of the Orbieu basin, we obtain the decomposition in 2 subdomains as shown in Fig. 11 below (white regions versus dark regions). To apply the criteria, we used a rough a priori estimation of the water height over the basin based on the rainfall rates forecasted in the official warning bulletins $(30 \mathrm{~mm} / \mathrm{h}$ in Eq. (11). The
HESSD

3, 3397-3438, 2006

\section{MARINE distributed model for flash flood modeling}

V. Estupina-Borrell et al.

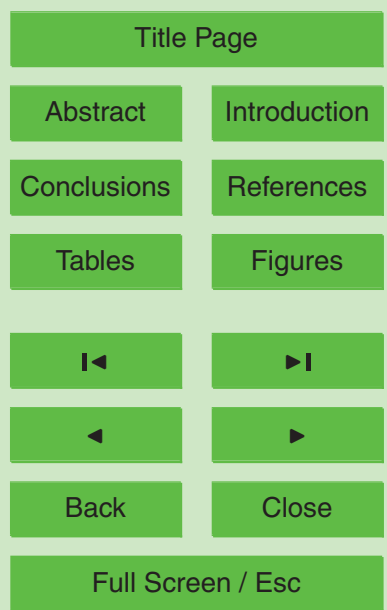

Printer-friendly Version

Interactive Discussion 
dark regions represent the pixels of the watershed where our criteria forbid the use of the cinematic wave approximation. One can observe that these computed dark pixels actually match fairly well the main river and a few of its tributaries. The hydraulic stream flow module of Marine will be used for these pixels. Precise that there is no specific 5 treatment in this study, the only one treatment is the one realized on the DEM for the lagragian resolution presented part 2.2. The hydrographic network appears from the DEM and the spatial distribution of " $F$ " an " $k$ " only (Fig. 12).

This delineation is obtained for a DEM pixel size of $50 \mathrm{~m}$. In the case of a $100 \mathrm{~m}$ resolution, the delineation between watershed and stream flow modules would have 10 almost been the same.

The data to get should have a resolution of about $50 \mathrm{~m}$, but once the pretreatment of MARINE done it is possible to define a data pixel size with a rougher resolution for MARINE resolution (until $1000 \mathrm{~m}$ ).

\subsection{Sensitivity of model with respect to initial water content}

Different sensitivity tests on the initial soil water content condition for flash floods show that this initial condition is not as important as it is for other kind of floods (Fig. 13). They put in evidence that, in our context and in front of the existing uncertainties on the observations and rainfall, it is acceptable to work on a discrete field of initial water content values: $0,25,50,75,100 \%$.

20 For the Green and Ampt model, it can be explained by the fact that the pounding time is quite short because of the important rainfall intensities from the very start of the event. So the effective infiltration rate is the potential infiltrability of the soil. In this case, more the effective hydraulic conductivity is important, more the infiltrated volume rapidly increases and less the initial value of the soil humidity influences.

25 Even if the surface soil water content of the soil can be access from spatial techniques, it can not be faced to integrate this information in a real time context. Our methodology is based on a simplified assimilation technique. It consists in following the 5 possible hydrographs, each one with characteristic soil water content $(0 \%, 25 \%$,
HESSD

3, 3397-3438, 2006

\section{MARINE distributed model for flash flood modeling}

V. Estupina-Borrell et al.

Title Page

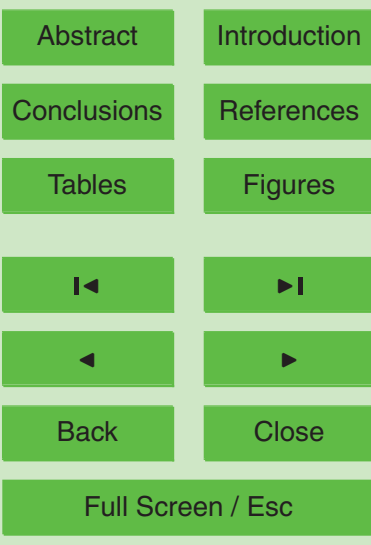

Printer-friendly Version

Interactive Discussion 
$50 \%, 75 \%, 100 \%$ ), and the real time observations of the outlet flow to choice the well fitted initial condition between the 5 tested. This operation is done only on the first time steps of the floods during the rising curve until the level of alarm of the river is reached. Initial soil water content (or more generally the initial saturation state of the 5 watershed, including both soil water content and depth of shallow groundwater) is an open problem, still being explored... Moreover, the relatively slow evolutions of subsurface moisture and water table may not be as important for the type of flash floods investigated here, as they would be for slower types of floods.

\subsection{Calibration and data assimilation}

10 Vieux et al. (2004) demonstrates that physically based distributed models, which are formulated to make runoff predictions using parameters derived form physically watershed properties, can be a priori calibrate with geospatial data only (terrain, soil, land cover). Even if this calibration would be improve using past rain and flow observations, a limited number of events could allow to converge towards an optimal calibration (including more events materially does not change the calibration).

In this case, in front of the lack of past observed events, the parameters of MARINE are the geospatial derived one. They could be adjusted to counterbalance the hypothesis of homogeneity of the model pixel done for the upscaling or to take into account the different uncertainties on the data or approximations of the model, but this stage would need other observations of flash floods on this watershed.

The Manning coefficients on the hillslopes are interpreted thanks to its tabulated values proposed by Chow (1959) from the land cover map. For example, as is the case here for the Orbieu watershed, a vegetation cover comprising dense trees over $70 \%$ of its area is represented, hydraulically, by a Manning coefficient $n \approx 0.1 \mathrm{SI}$.

25 The hydraulic roughness of the main channel was estimated, thanks to in situ observations of the river bed, the Manning hydraulic roughness coefficient (" $n$ ") of the main channel was between 0.05 to $0.1 \mathrm{SI}$ (the equivalent Stikler hydraulic roughness coefficient was between 10 to $20 \mathrm{SI}$ ).

\section{HESSD}

3, 3397-3438, 2006

\section{MARINE distributed model for flash flood modeling}

V. Estupina-Borrell et al.

Title Page

Abstract

Introduction

Conclusions

Tables

References

Figures

14

$\rightarrow$

4

Back

Close

Full Screen / Esc

Printer-friendly Version

Interactive Discussion 
The soil texture class is clay loam and sandy clay loam. The corresponding constant infiltration rate is $\mathbf{0 . 5}$. The Horton parameters are fixed in accordance with a loamy soil and with the Holtan model $\left(f_{o}=4^{\star} f_{c}\right)$ and $\beta$ at $0.1 \mathrm{~min}-1$. The matching Green and Ampt infiltration parameters are a porosity of 0.464 and 0.398 , a wetting front soil of $0.2088 \mathrm{~m}$ and $0.2185 \mathrm{~m}$ (these values are the ones proposed by Maidment (1993)).

The calibrations of saturated hydraulic conductivity and of the initial water content of the soil are realized step by step with the simplified data assimilation technique presented above during the first hours of the flood. For the Horton infiltration rate model, this procedure yields an infiltration rate capacity $\left(f_{c}\right)$ of $1.5 \mathrm{~mm} / \mathrm{h}$, and for the 10 Green and Ampt model, an initial soil water content of $0 \%$ and a saturated hydraulic conductivity of $1.5 \mathrm{~mm} / \mathrm{h}$.

\subsection{Rainfall estimation and spatialisation}

First, let us define "spatialisation". Spatialisation can be understood here as estimation, interpolation, extrapolation of rainfall in $(x, y)$ space; also the problem of aggregating 15 or disaggregating rainfall on the desired pixel sizes (e.g.: from $\Delta \times_{\text {RAIN }}$ to $\Delta \times_{\text {DEM }}$ ); and finally, the problem of taking into account temporal resolution (particularly for nonstationary storms).

For instance, Tetzlaff et al. (2005) demonstrates the considerable importance of rainfall spatialisation and its consequence on the basin response (hydrographs) depending on the kind of storm/flood event being studied.

In the case at hand, we have only 3 rain gauges and some cumulated rain radar images, but nevertheless, some of our tests (not all described here) indicate that they provide a sufficiently reasonable (robust) representation of the space-time rainfall pattern. Furthermore, the temporal resolution used in this specific case for rainfall is quite precise $\left(\Delta t_{\mathrm{RAIN}}=15 \mathrm{~min}\right)$. But the extremely heterogeneous character of rainfalls generating such a flash flood may not be not correctly reproduced in the input data used and so may generate some uncertainties.

\section{HESSD}

3, 3397-3438, 2006

\section{MARINE distributed model for flash flood modeling}

V. Estupina-Borrell et al.

Title Page

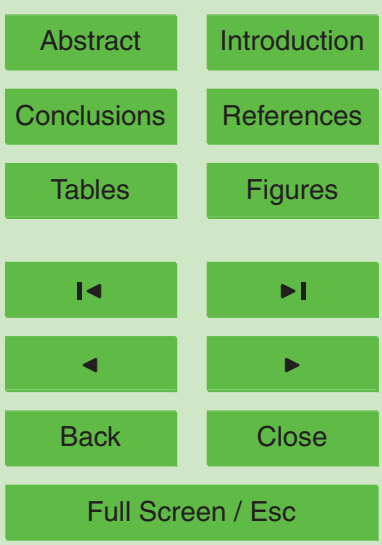

Printer-friendly Version

Interactive Discussion 


\section{Application and test of the model: simulation results and discussion}

\subsection{Flash flood simulation results: flood hydrographs}

HESSD

The results of the simulations obtained with Marine for the Lagrasse flash flood of November 1999 on the Orbieu basin, are presented and discussed in this section 5 (Fig. 14).

Gaume et al. (2004) explain that this specific flood is mainly due to fast responding hydrological processes, the reactivity of the watershed to fluctuations in rainfall intensity is important. Indeed, the first observed hydrograph peak (about $550 \mathrm{~m}^{3} / \mathrm{s}$ ) is produced by the pluviograph peak observed at Lagrasse. The third observed hydrograph peak 10 (about $\left.220 \mathrm{~m}^{3} / \mathrm{s}\right)$ is probably due to the pluviograph peak observed at Bouisse $(11 \mathrm{~h}$ later than the one of Lagrasse plus the delay time due to the time routing of the water between upstream and dowstream parts of the basin). But the second hydrograph peak (about $350 \mathrm{~m}^{3} / \mathrm{s}$ ) can not find explanation within the rainfall data available. Furthermore the very rapid decreasing and rising of the flow may reforce the thesis of errors on water elevation measurements in the river bed or wrong interpretation of them (debris).

The study of Gaume et al. (2004) of the same flood that occurred on a smaller neighborhood basin shows (among all) that the amount of losses by infiltration for this flood is about $200 \mathrm{~mm}$ and occurred mainly at the beginning of the event. Furthermore, it supposes that the type of land cover of the basin is of second importance during this 20 event.

The present study confirms these points:

- The calibrated infiltration coefficient, regardless of the type of infiltration model being used, shows that a considerable part of the rain was stored in the soil during this flood (from 100 to $200 \mathrm{~mm}$ ).

- The behavior of the woody watershed of this study seems to be equivalent in lots points of the watershed mainly occupied by vineyards and scrubs of the precedent

\section{MARINE distributed model for flash flood modeling}

V. Estupina-Borrell et al.

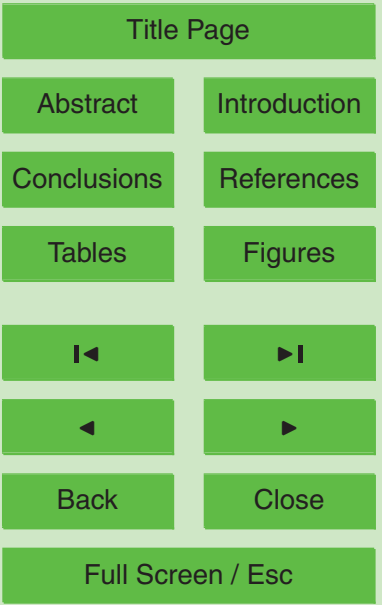

Printer-friendly Version

Interactive Discussion 
study. This observation confirms the hypothesis as the type of land use seems to be of second importance during this event.

HESSD

3, 3397-3438, 2006

5.2 Discussion of simulated vs. observed flood hydrographs

The results of the simulations realized with the different modules of MARINE are quite 5 similar in their global form and timing, but their amplitude can be different.

The rising curve of the first observed hydrograph peak (about $550 \mathrm{~m}^{3} / \mathrm{s}$ ), the recession curve of the second observed flood hydrograph peak (about $350 \mathrm{~m}^{3} / \mathrm{s}$ ) and the third observed hydrograph peak (about $220 \mathrm{~m}^{3} / \mathrm{s}$ ) are comprised between the upper and the lower envelopes defined by the different simulations.

10 Two parts of the observed hydrograph: the second observed peak (about $350 \mathrm{~m}^{33} / \mathrm{s}$ ) (probably wrong, see just below) and the end part of the recession curve of the hydrograph (the recession curve of the third peak of about $220 \mathrm{~m}^{3} / \mathrm{s}$ ). The second mismatch can be explained by the observed rain data used for the simulation. The three precipitation gauges spatialised and corrected with a Thiessen repartition and with the radar meteorological cumulated precipitation data do not supply very satisfactory precipitation field.

One can observe that the infiltration module with the constant rate supplies quite good results for real time forecasting. For the Horton concept, this can be explained by the fact that in less than one hour, the value of the exponential term of the equation 20 becomes negligible compared to the value of the saturated hydraulic conductivity $\left(f_{c}\right)$. So this model quickly behaves like a constant one. For the Green and Ampt model, the behavior of the simulated hydrograph is quite different. It first presents a delay in the starting point of the rising curve compared with the constant rate model and the Horton model, and than it presents a more rapid rising curve.

25 Admittedly, these results could have be improved by a direct calibration of the model on the observed flash flood hydrograph, but this methodology does not enter within the framework of our research.

\section{MARINE distributed model for flash flood modeling}

V. Estupina-Borrell et al.

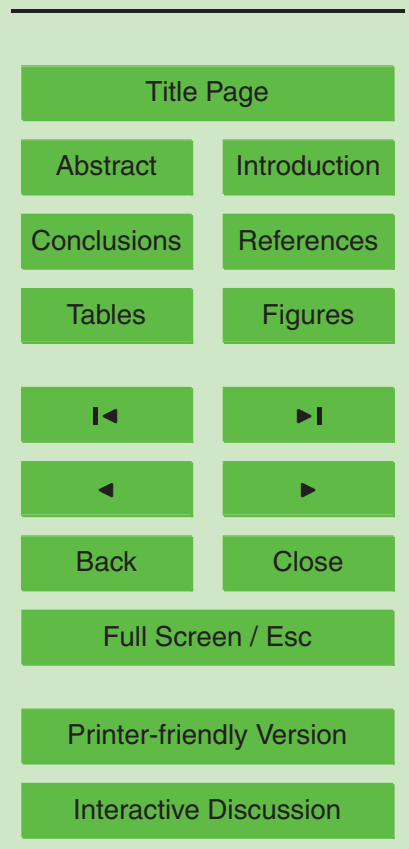

EGU 


\section{Conclusions}

MARINE was formulated to make flash floods prediction caused by surface runoff process. In front of the rareness, violence and rapidity of flash floods, MARINE had to find its necessary data for calibration outside the classical measurements and obser5 vations.

That is the reason why MARINE is a physically based hydrological distributed model. Its physically distributed character allows the a priori calibration of its most parameters. The remotely sensed data can be used for this goal. Some adaptations specific to the hydrology field have to be done and more particularly the scale of definition of these images has to be taken into account. Then spatial DEMs or land cover maps can be used as data for flash flood forecasting.

Another important issue concerns the calibration (or data assimilation) of the model with respect to the initial saturation state of the basin. In this case, we have adjusted the initial conditions (initial water content in the soil) or other sensitive parameters (hydraulic conductivity of the soil) with the first observed flow at the outlet of the basin (until the level of alert is reached). But, more generally, this issue is open and coupled with the equifinality issue; some more investigations have to be realized to improve this technique (keeping in mind the necessary rapidity of the model to use).

Nevertheless the results obtained on the flash flood of November 1999 in the southern France indicate that this particular model is able to reproduce the hydraulic behavior of the watershed.

Furthermore, the MARINE model was initially designed for real time forecasting, implying the following constraints:

- Sufficiently short computational time (CPU time);

- Data requirements compatible with the type of data actually available in real time;

- Model results (model outputs) formulated in accordance with the forecaster's needs.
HESSD

3, 3397-3438, 2006

\section{MARINE distributed model for flash flood modeling}

V. Estupina-Borrell et al.

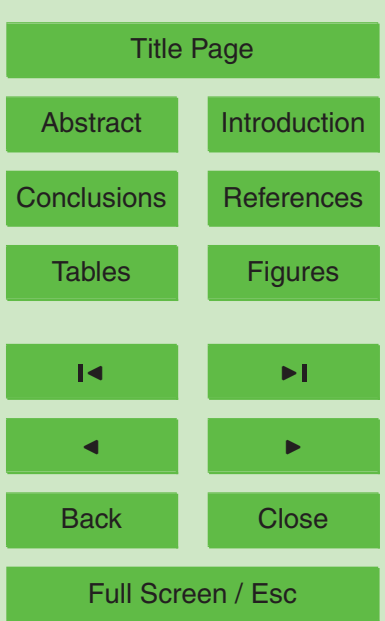

Printer-friendly Version

Interactive Discussion 
MARINE is the formulation of a relatively basic physical approach with adequate numerical method. This particularity makes this model conform to the objectives of forecasting flash floods with a sufficient precision.

To test its applicability in real time conditions, MARINE was introduced inside the 5 PACTES project by Alquier et al. (2002). PACTES started in January 2000 for a two years pre-operational application project. It was lead by the French Ministry of Research and the French Space Agency CNES. PACTES traduces the will to improve the management of the flooding risk over its different phases (prevention, early warning, crisis and post-crisis). It is a transverse and multi-disciplinary operation which asso10 ciates the operational users (Civil Protection, Flood Warning Services, regional land planning services), the meteorological and hydrological researchers and the space industry.

The objectives of this project are to integrate advanced modeling techniques, to use space techniques, to combine different sources of information for decision support, and to allow the different actors to share information and to exchange it in real-time during alert and crisis phases. This project leads to development of a pre-operational demonstrator which is a distributed information system, based on GIS and Internet technologies. It was applied on the French watershed of the Thore river, in the Tarn department. First back up from this experience show that MARINE is adapted to the real time operational forecasting conditions.

Acknowledgements. This research was carried out at the Institute of Fluid Mechanics of Toulouse (IMFT). The authors are particularly grateful for the help provided by the IMFT Surface Hydrology team. The authors would also like to thank C. Puech at the "Maison de la Télédétection" in Montpellier, J. M. Tanguy at the SCHAPI in Toulouse, the SCOT company 25 in Toulouse for their technical and financial support, and the DDE-11 who provided some of the data used in this study. Finally, the authors extend their thanks to every partner and data provider of the PACTES research project, namely: ADAGE Dvpt, Alcatel Space Industries, ASTRIUM, BRGM, CEMAGREF, Civil Security, CNES, EADS S\&DE, Flood Alert Services, French Ministry of Research, French Ministry of Environment, IGN, IMFT, IRIT, Météo France, SERTIT, SCOT and SPOT Image.

\section{HESSD}

3, 3397-3438, 2006

\section{MARINE distributed model for flash flood modeling}

V. Estupina-Borrell et al.

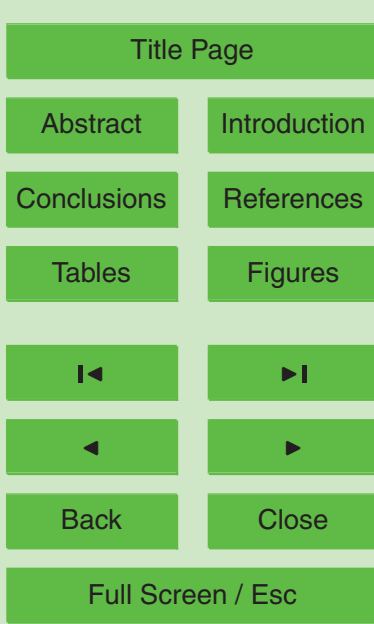

Printer-friendly Version

Interactive Discussion 


\section{References}

Ababou, R. and Trégarot, G., Coupled Modeling of Partially Saturated Flows: Macro-Porous Media, Interfaces, and Variability. Proc. CMWR 2002: Comput. Methods in Water Resources (23-28 June 2002, Delft, The Netherlands), Comput. Mech. Publi, 8pp, 2002.

5 Albergel, J.: Le modèle hortonien: genèse des crues et des inondations, Ed. SHF, Paris, ENGREF, 10-15, 2003.

Alquier, M., Chorda, J., Dartus, D., Estupina Borrell, V., Llovel, C., and Maubourguet, M. M.: PACTES: La chaîne de prévision du Thoré, Research Contract, IMFT, Toulouse, 2002.

Booij, M. J.: Appropriate modelling of climate change impacts on river flooding, Twente, 206pp, 2002.

Borgniet, L., Estupina-Borrell, V., Dartus, D., and Puech., C.: Methodologies for analyzing intrinsic and required DEM accuracy for hydrological applications of flash floods. Canadian Journal of Remote Sensing. Special collection: Applications of remote sensing in hydrology, 29(6), 734-740, 2003.

15 Bousquet, J. C.: Géologie du Languedoc Roussillon, Les presses du Languedoc, Editions du BRGM, 1997.

Carluer, N.: Vers une modélisation hydrologique adaptée à l'évaluation des pollutions diffuses: prise en compte du réseau anthropique, Pierre et Marie Curie, Lyon, 386pp, 1998.

Chahinian, N., Moussa,, R., Andrieux, P., and Voltz. M.: Comparison of infiltration models to simulate flood events at the field scale, J. Hydrol., 306(1-4), 191-214, 2005.

Chow, V. T.: Open Channel Hydraulics edited by: Davis, H. E. (consulting Editor), 680pp, 1959.

Cosandey, C. and Robinson, M.: Hydrologie continentale, Armand Colin, Paris, 360 p., 2000,

Datin, R.: Outils opérationnels pour la prévision des crues rapides: traitement des incertitudes et intégration des prévisions météorologiques, Développements de TOPMODEL pour la prise en compte de la variabilité spatiale de la pluie. Application au bassin versant de l'Ardèche, Thèse INPG, Grenoble, 266pp, 1998.

Estupina-Borrell, V. and Dartus, D.: La télédé-tection au service de la prévision opèrationnelle des crues éclair, Bulletin de la Société Francaise de Photogrametrie et de Télédetection, 4, 31-39, 2003.

30 Estupina, V., Llovel, C., Maubourguet, M. M., Chorda, J., Dartus, D., Ababou, R., and Alquier, M.: Flash Flood Modeling for Prediction, Warning and Risk Assessment. In: Trends der Wasserwirtschaft 33.IWASA Internat, Wasserbau-Symposium, Aachen 2003, RWTH Univ.

\section{HESSD}

3, 3397-3438, 2006

\section{MARINE distributed model for flash flood modeling}

V. Estupina-Borrell et al.

Title Page

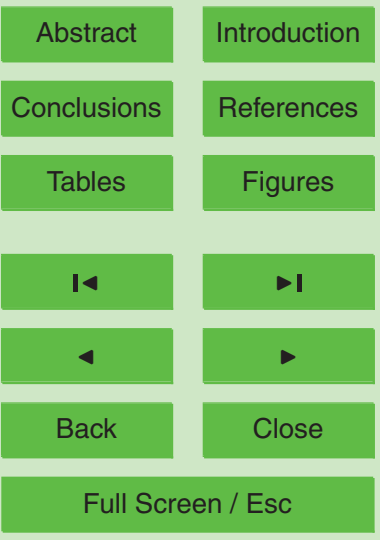

Printer-friendly Version

Interactive Discussion 
Aachen, Institut Wasserbau \& Wasserwirtschaft: Mitteilunge, Shaker Verlag, Aachen ISBN 3-8322-3083-1, Germany, 175-223, 2004.

Estupina-Borrell, V.: Vers une Modélisation Hydrologique adaptée à la Prévision Opérationnelle des Crues Eclair - Application à de Petits Bassins du Sud de la France, Thèse INPT,

5 Toulouse, , 241p, 2004.

Estupina-Borrell, V., Chorda, J., and Dartus, D.: Flash floods anticipation / Prévision des crues éclair, Comptes rendus Geosci., 337, 13, 1109-1119, 2005.

Foody, G. M., Ghoneim, E. M., and Arnell, N. W.: Predicting locations sensitive to flash flooding in an arid environment, J. Hydrol., 292, 1-4, 48-58, 2004.

10 Gaume E., Livet, M., Desbordes, M., and Villeneuve., J. P.: Hydrological analysis of the rver Aude, France, flash flood on 12 and 13 Novembre 1999, J. Hydrol., 286, 1-4, 135-154, 2004.

Giraud, F., Faure, J. B., Zimmer, D., Lefeuvre, J. C., and Skaggs, R. W.: Modélisation hydrologique d'une zone humide complexe, J. irrigation, 123(5), 1531-1540, 1997.

Henderson, F. and Wooding, R.: Overland flow and groundwater from a steady rainfall of finite

15 duration, J. Geophys. Res., 69(8), 1531-13540, 1964.

Horton, R. E.: An approach toward a physical interpretation of infiltration-capacity, Soil Sc. Soc. Am., 5, 399-417, 1940

IAHS, UNESCO, WMO: Flash floods, Proceedings of the Paris symposium, edited by: IAHSUNESCO-WMO, 112, 1974.

20 Liu, Z. and Todini, E.: Towards a comprehensive physically-based rainfall runoff model, Hydrol. Earth Syst. Sci., 6(5), 859-881, 2002.

Maidment, D. R.: Handbook of Hydrology, Publisher: McGraw-Hill Professional, 1424, 1993,

Mallants, D. and Feyen, J.: Quantitative and qualitative aspects of surface and groundwater flow, 2, KUL, 96, 1990

Meentemeyer, V.: Geographical perspectives of space, time and scale, Landscape Ecology., 3, 163-173, 1989.

Montz, B. E. and Gruntfest, E.: Flash flood mitigation: recommandations for research and applications, Environ-mental Hazards, 1-15, 2002.

Moore, I. D. and Foster, G. R.: Hydraulics and overland flow, Process studies in hillslope re-

30 search, edited by: Anderson, M. G. and Burt, T. P., John Wiley and sons, 215-254, 1990.

Puech, C.: Utilisation de la télédétection et des modèles numériques de terrain pour la connaissance du fonctionnement des hydrosystèmes, UMR35, CEMAGREF ENGREF, Montpellier, 2000.

HESSD

3, 3397-3438, 2006

MARINE distributed model for flash flood modeling

V. Estupina-Borrell et al.

Title Page

Abstract

Introduction

Conclusions

Tables

References

Figures

14

$\rightarrow$

4

Back

Close

Full Screen / Esc

Printer-friendly Version

Interactive Discussion 
Rodriguez-Iturbe, I., Mejia, J. M.: On the transformation from point rainfall to areal rainfall. Water Resour. Res., 10 (4), 729-735, 1974.

Sivapalan, M. and Bloschl, G.: Transformation of point rainfall to areal rainfall: Intensityduration-frequency curves, J. Hydrol., 204(1-4), 150-167, 1998.

5 Tetzlaff, D. and Uhlenbrook, S.: Significance of spatial variability in precipitation for processoriented modelling: results from two nested catchments using radar and ground station data, Hydrol. Earth Syst. Sci., 9, 29-41, 2005.

Vieux, B. E., Cui, Z., and Gaur, A.: Evaluation of a physics-based distributed hydrologic model for flood forecasting, J. Hydrol., 298, 1-4, 155-177, 2004.

10 Walsh, S. J., Crawford, T. W., Welsh, W. F., and Crews-Meyer, K. A.: A multiscale analysis of LULC and NDVI variation in Nang Rong district, northeast Thailand, Agriculture, Ecosyst. Environment., 85(1-3), 47-64, 2001.

\section{HESSD}

3, 3397-3438, 2006

\section{MARINE distributed model for flash flood modeling}

V. Estupina-Borrell et al.

Title Page

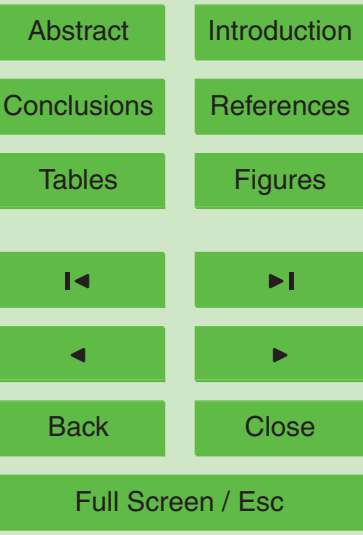

Printer-friendly Version

Interactive Discussion 


\section{HESSD}

\section{MARINE}
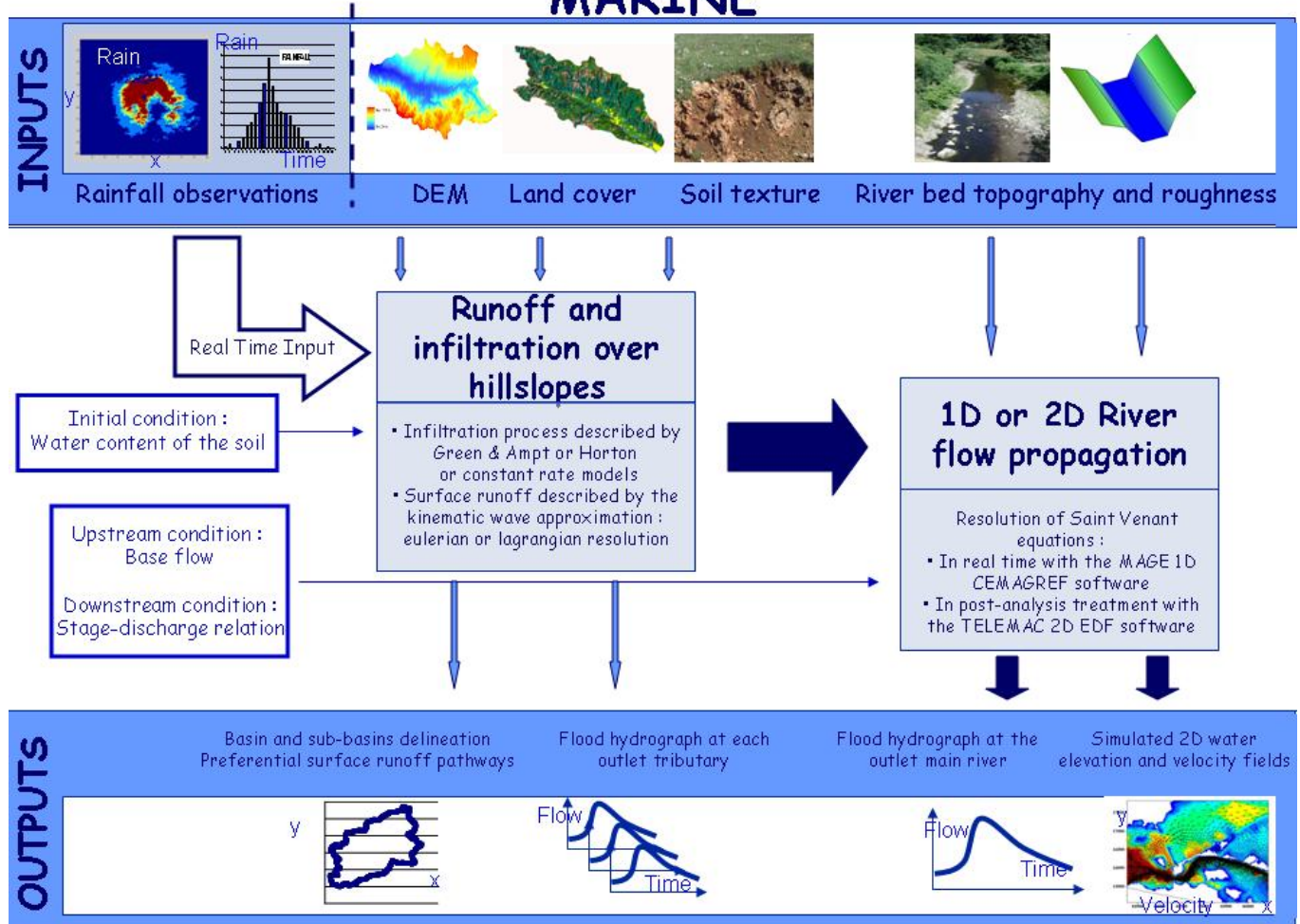

Fig. 1. General flow-chart of the MARINE hydrological model.
3, 3397-3438, 2006

\section{MARINE distributed model for flash flood modeling}

V. Estupina-Borrell et al.

Title Page

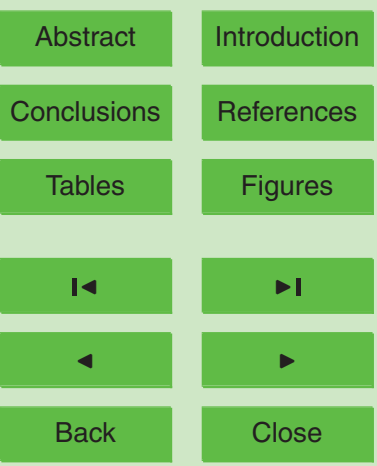

Full Screen / Esc

Printer-friendly Version

Interactive Discussion 


\section{HESSD}

3, 3397-3438, 2006

MARINE distributed model for flash flood modeling

V. Estupina-Borrell et al.

Title Page

Abstract

Introduction

Conclusions

References

Diffusion approximation

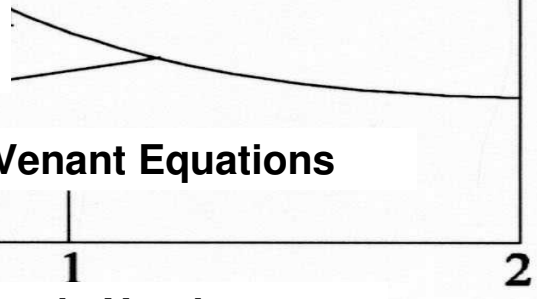

$F_{L}$ Froude Number

Fig. 2. Validity of the cinematic wave approximation according to Moore et al. (1990). 


\section{HESSD}

3, 3397-3438, 2006

\section{MARINE distributed model for flash flood modeling}
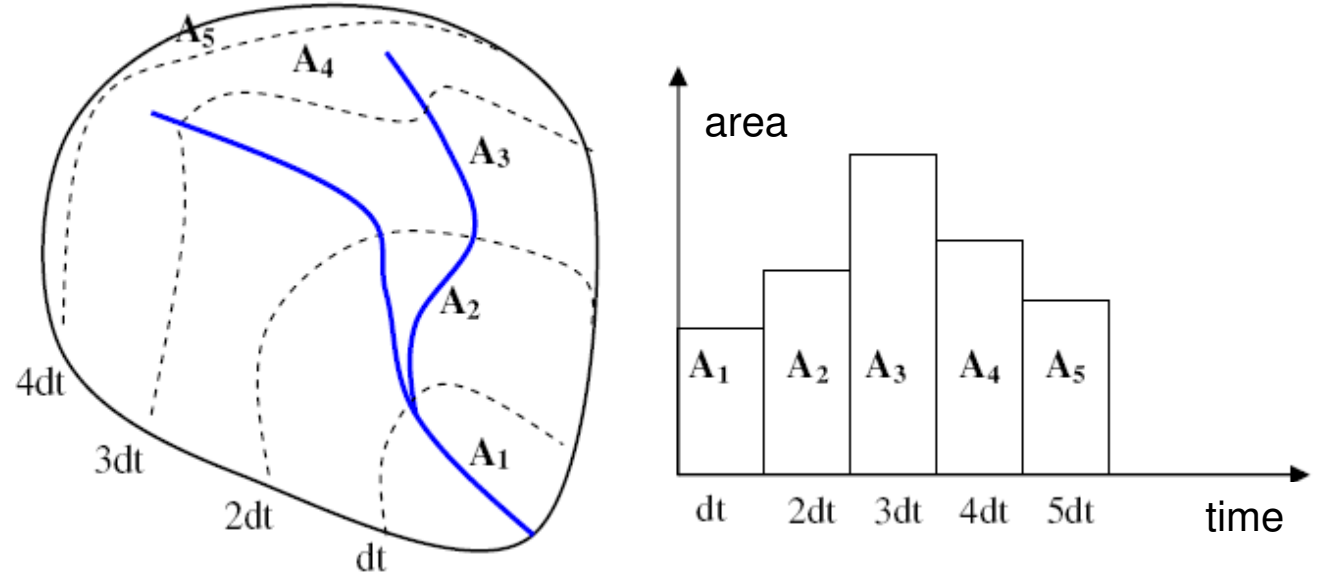

Fig. 3. Isochrones concept.
V. Estupina-Borrell et al.

Title Page

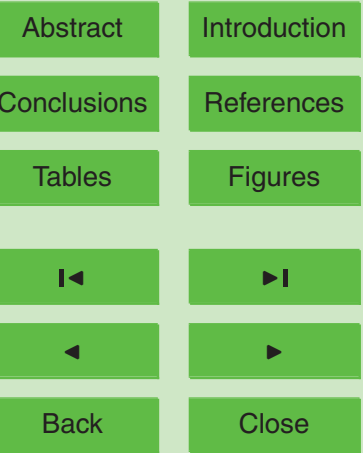

Full Screen / Esc

Printer-friendly Version 


\section{HESSD}

3, 3397-3438, 2006

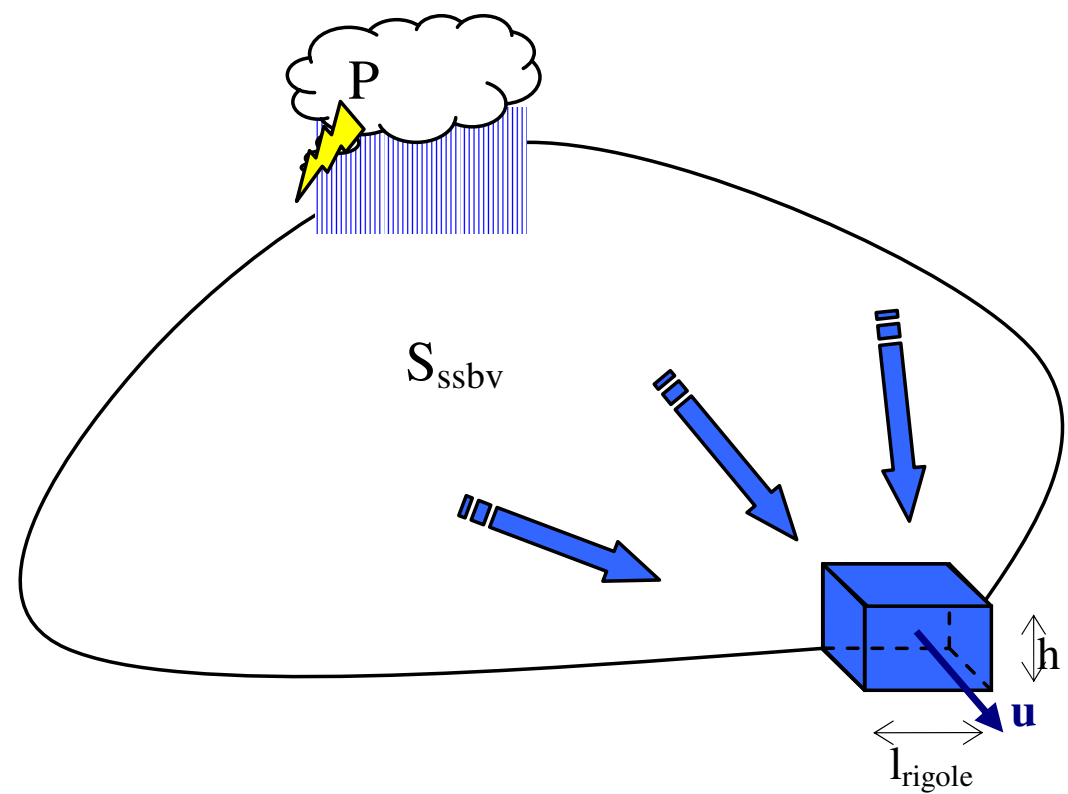

\section{MARINE distributed model for flash flood modeling}

V. Estupina-Borrell et al.

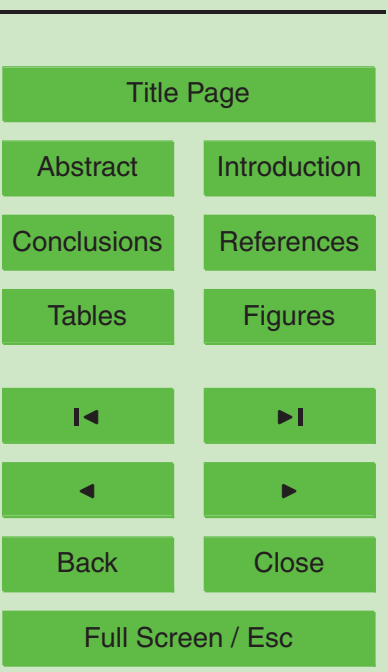

Fig. 4. Balance for the blue pixel size (Sssbv: area of the basin upstream the pixel, $u$ : water velocity on the pixel, $I_{\text {rigole }}$ : width of the "channel" draining water, $h$ : water depth on the pixel). 


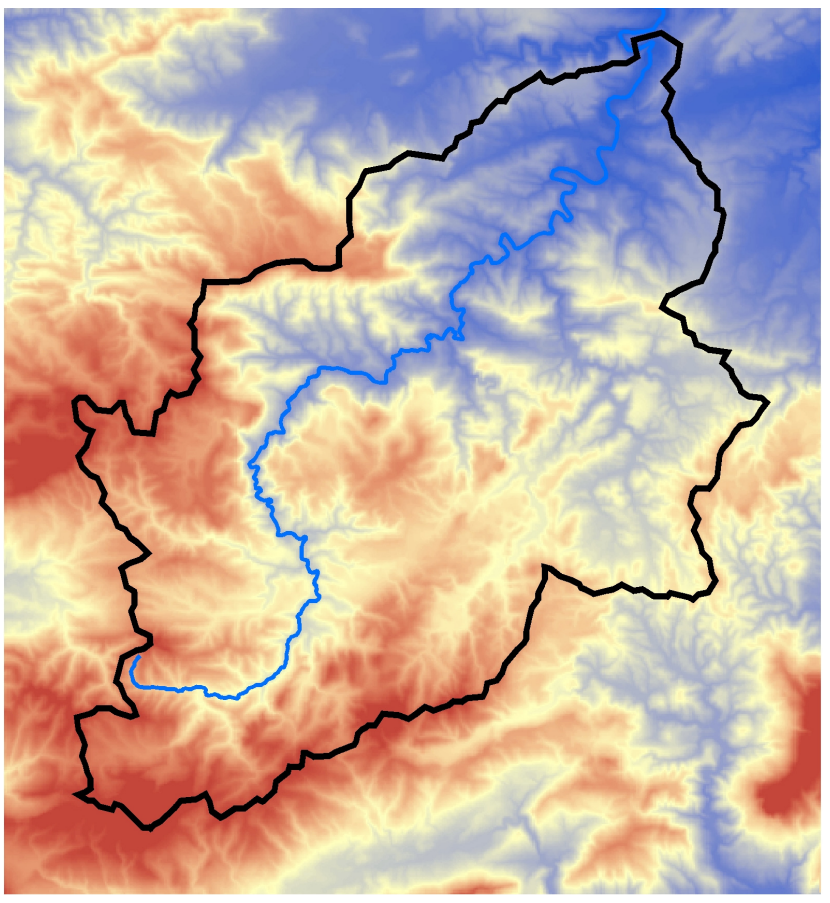

Fig. 5. DEM of the Orbieu basin upstream from Lagrasse (white delineation for the basin, black line for the river).

\section{HESSD}

3, 3397-3438, 2006

\section{MARINE distributed model for flash flood modeling}

V. Estupina-Borrell et al.

Title Page

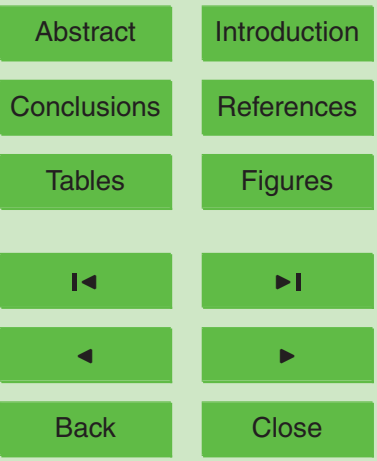

Full Screen / Esc

Printer-friendly Version

Interactive Discussion 


\section{HESSD}

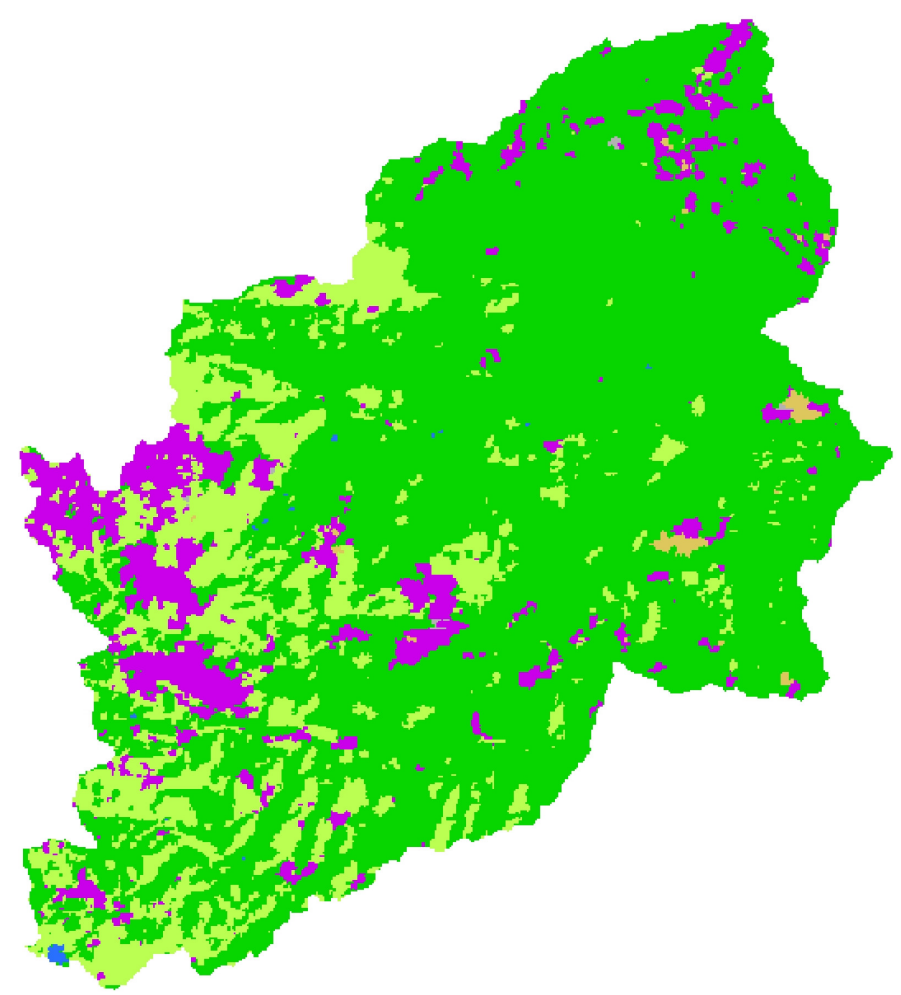

3, 3397-3438, 2006

\section{MARINE distributed model for flash flood modeling}

V. Estupina-Borrell et al.

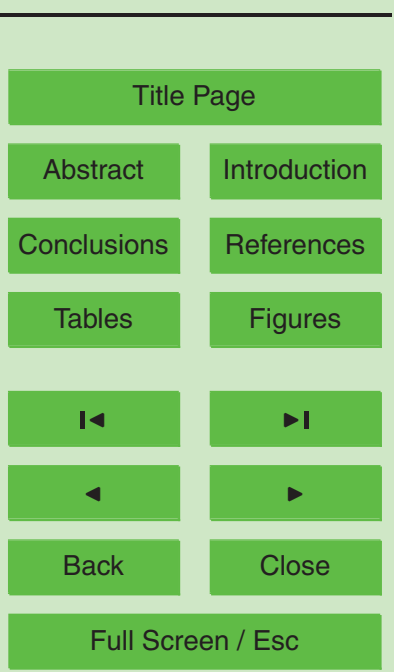

Fig. 6. Landcover map of the Orbieu basin upstream from Lagrasse (70\% of wood (green), $17 \%$ of grassland (ligth green), $12 \%$ of vigneyards (violet), others $(1.2 \%)$ ).
Printer-friendly Version

Interactive Discussion 


\section{HESSD}

3, 3397-3438, 2006

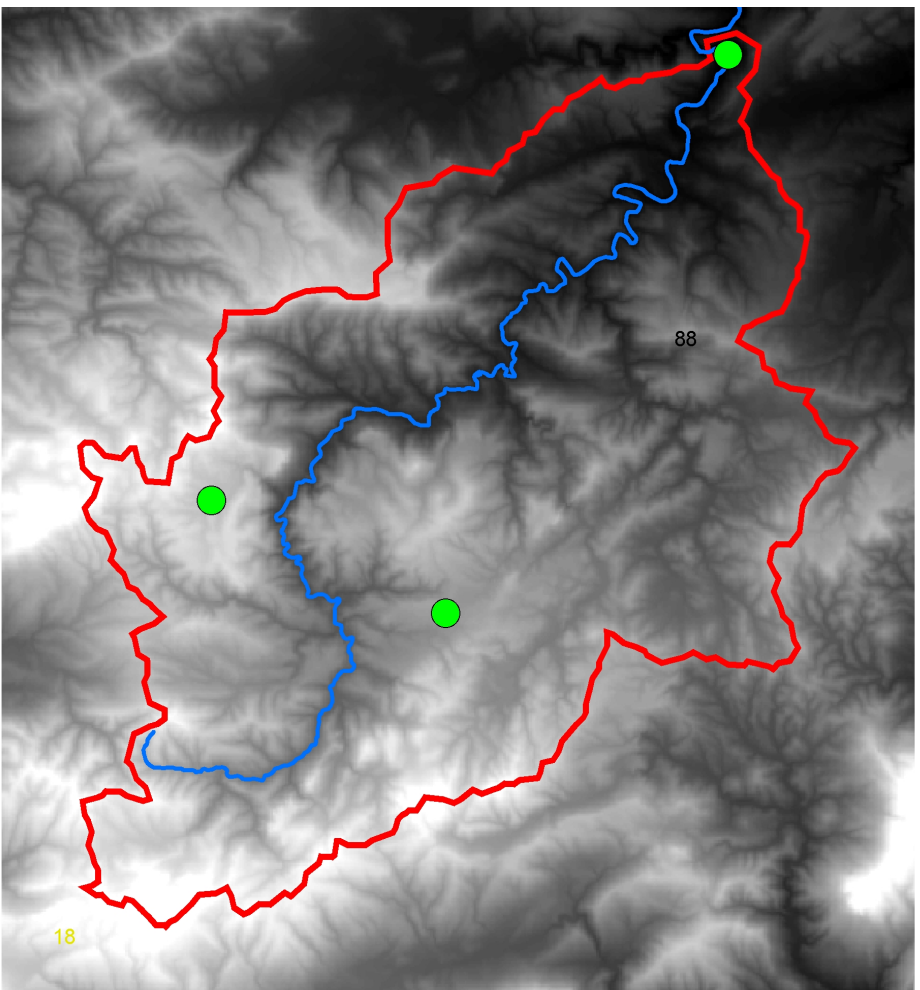

\section{MARINE distributed model for flash flood modeling}

V. Estupina-Borrell et al.

Title Page

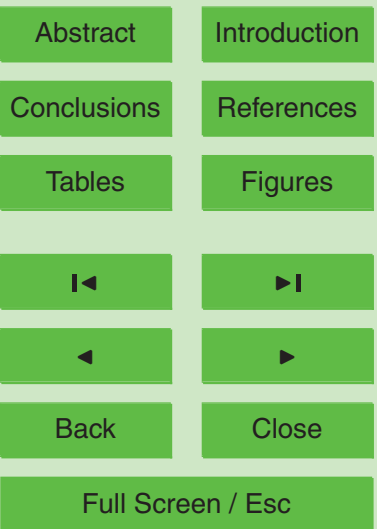

Printer-friendly Version

Interactive Discussion 


\section{HESSD}

3, 3397-3438, 2006

Rainfall - Aude November 1999

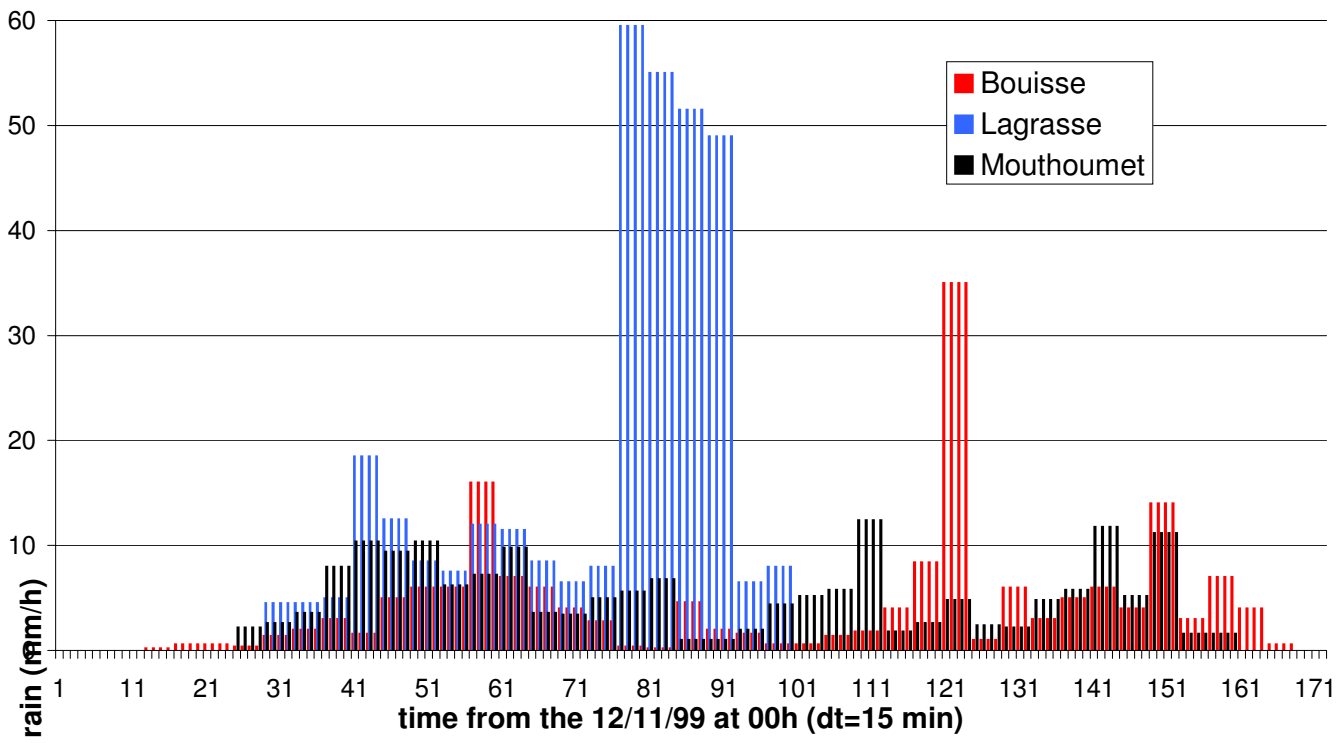

Fig. 8. Bouisse, Moutoumet and Lagrasse pluviographs (rain in $\mathrm{mm} / \mathrm{h}$ ).
MARINE distributed model for flash flood modeling

V. Estupina-Borrell et al.

\section{Title Page}

Abstract Introduction

Conclusions References

Tables

Figures

14

Back

Full Screen / Esc

Printer-friendly Version

Interactive Discussion 


\section{HESSD}

3, 3397-3438, 2006

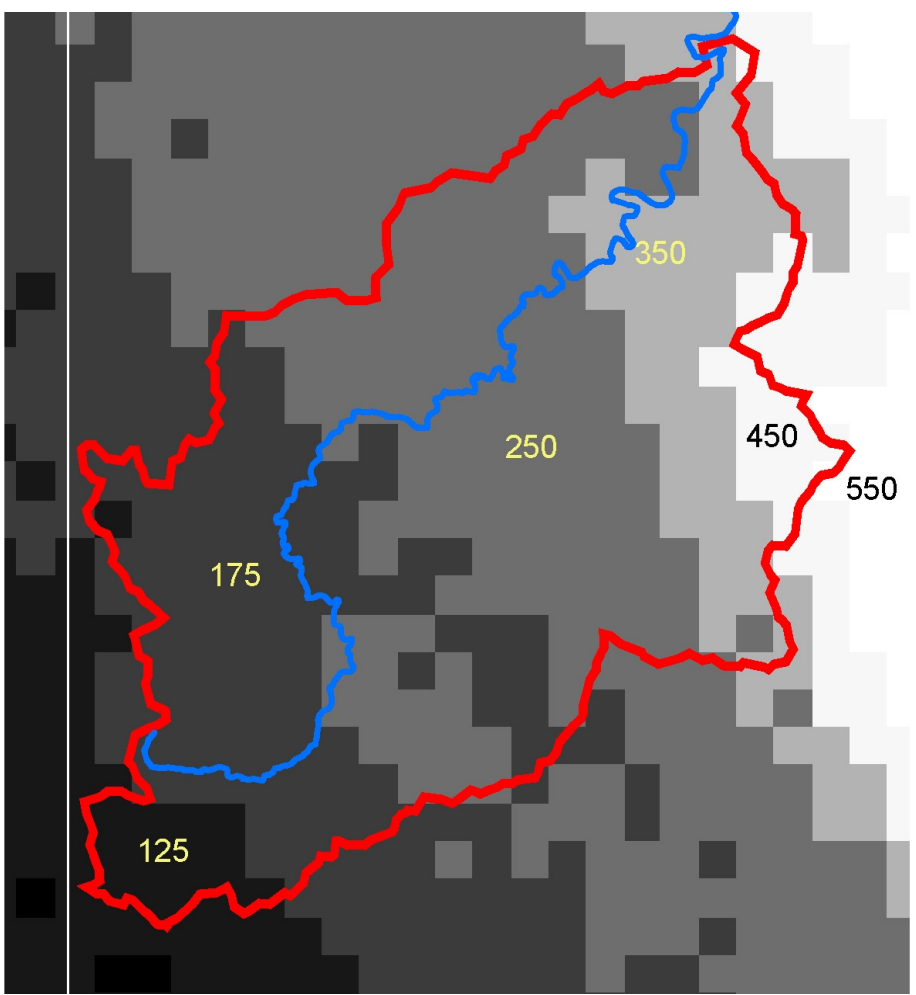

\section{MARINE distributed model for flash flood modeling}

V. Estupina-Borrell et al.

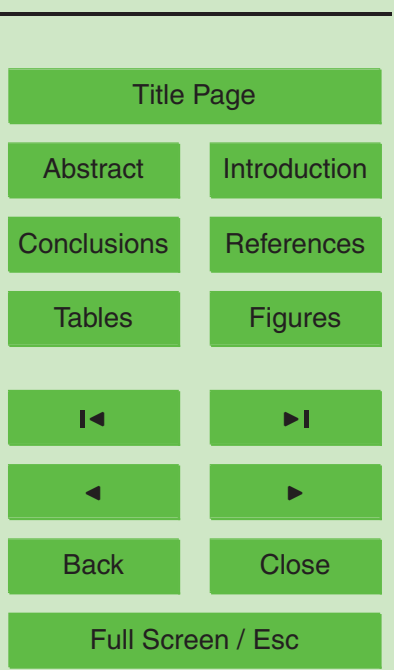

Fig. 9. Cumulated rainfall $(\mathrm{mm})$ observed with the meteorological radar for the flash flood of 1999.
Printer-friendly Version

Interactive Discussion 


\section{HESSD}

3, 3397-3438, 2006

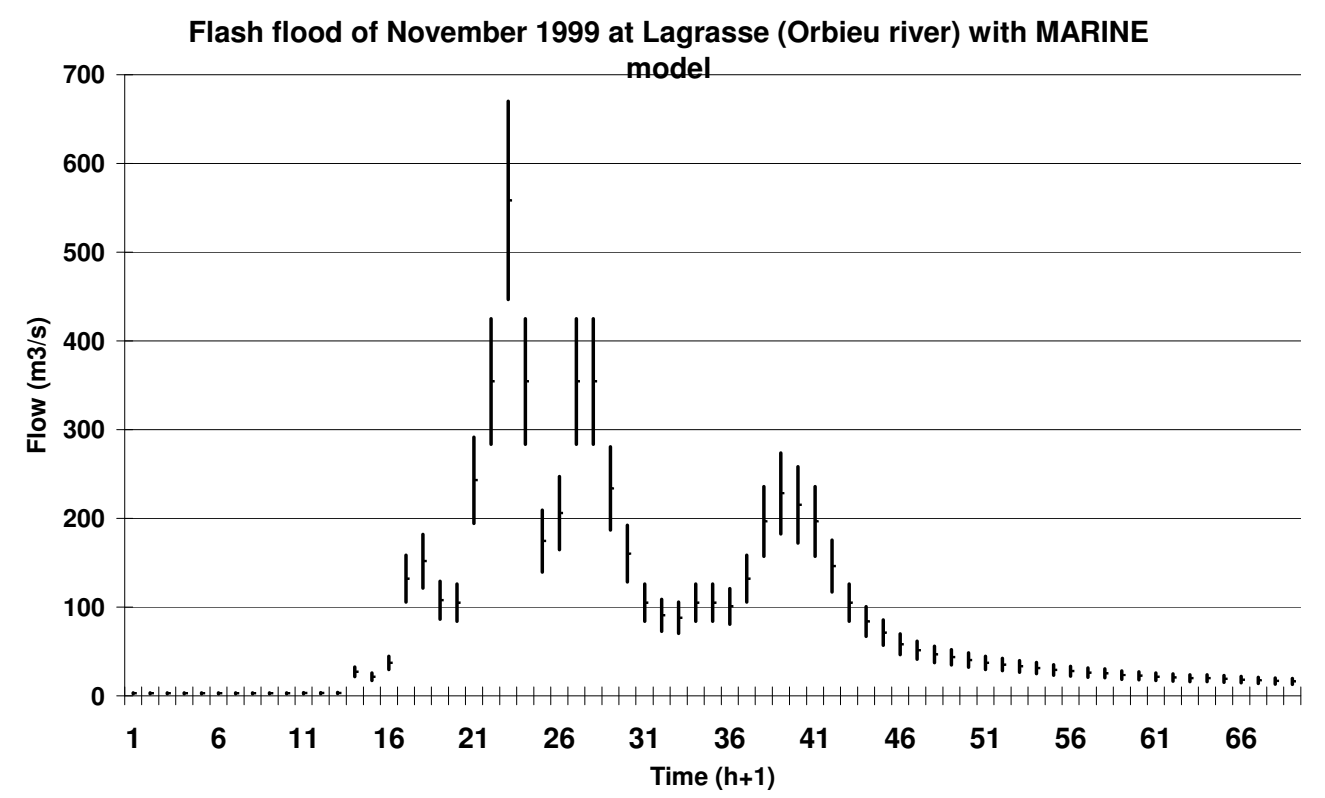

MARINE distributed model for flash flood modeling

V. Estupina-Borrell et al.

Title Page

Abstract

Introduction

Conclusions

References

Tables

Figures

14

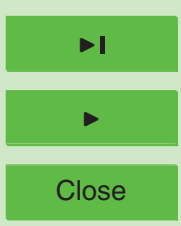

Back

Close

Full Screen / Esc

Printer-friendly Version

Interactive Discussion

EGU 


\section{HESSD}

3, 3397-3438, 2006

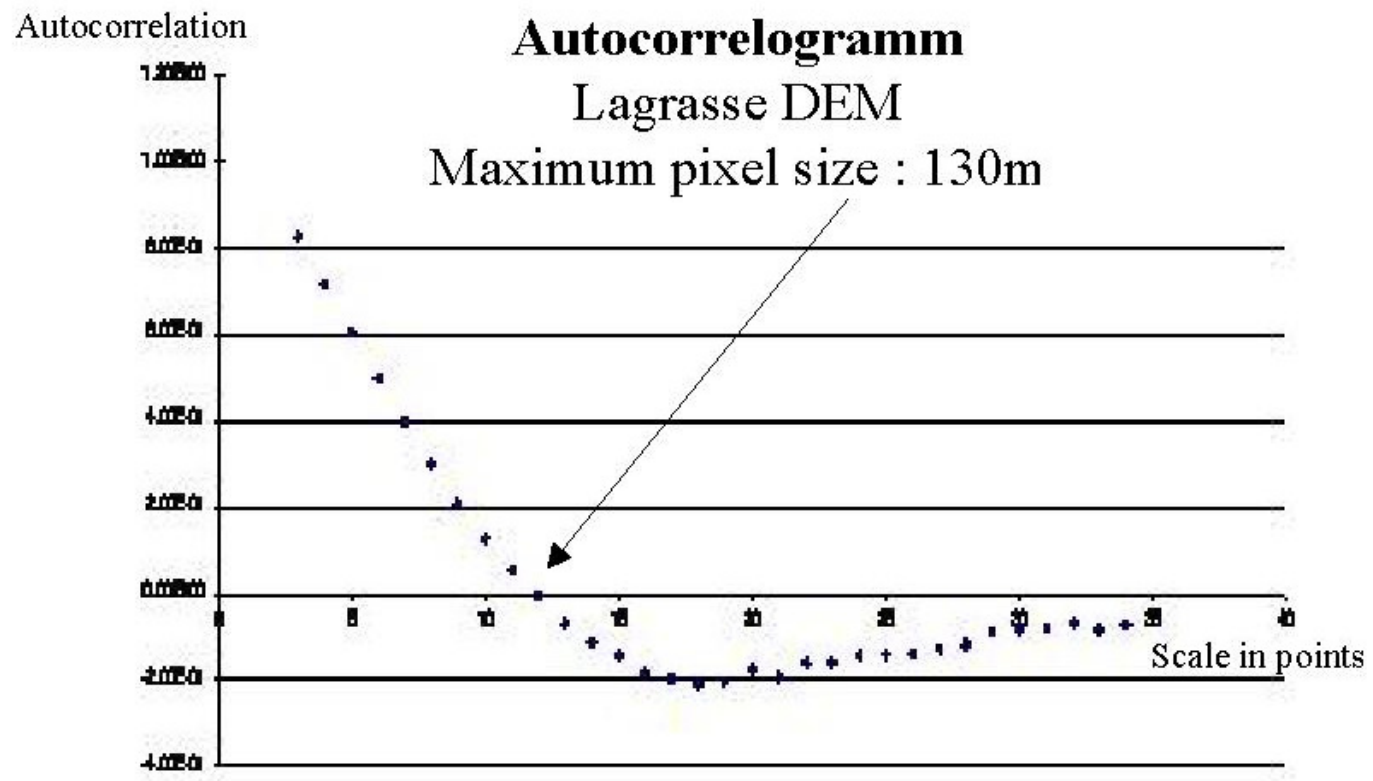

MARINE distributed model for flash flood modeling

V. Estupina-Borrell et al.

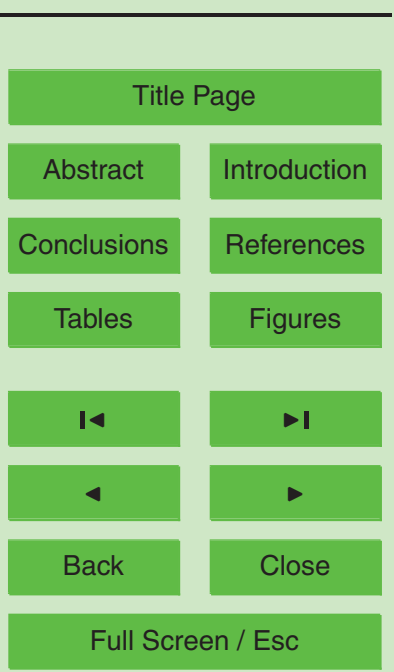

Fig. 11. Maximum pixel size defined by the autocorrelogram method. 


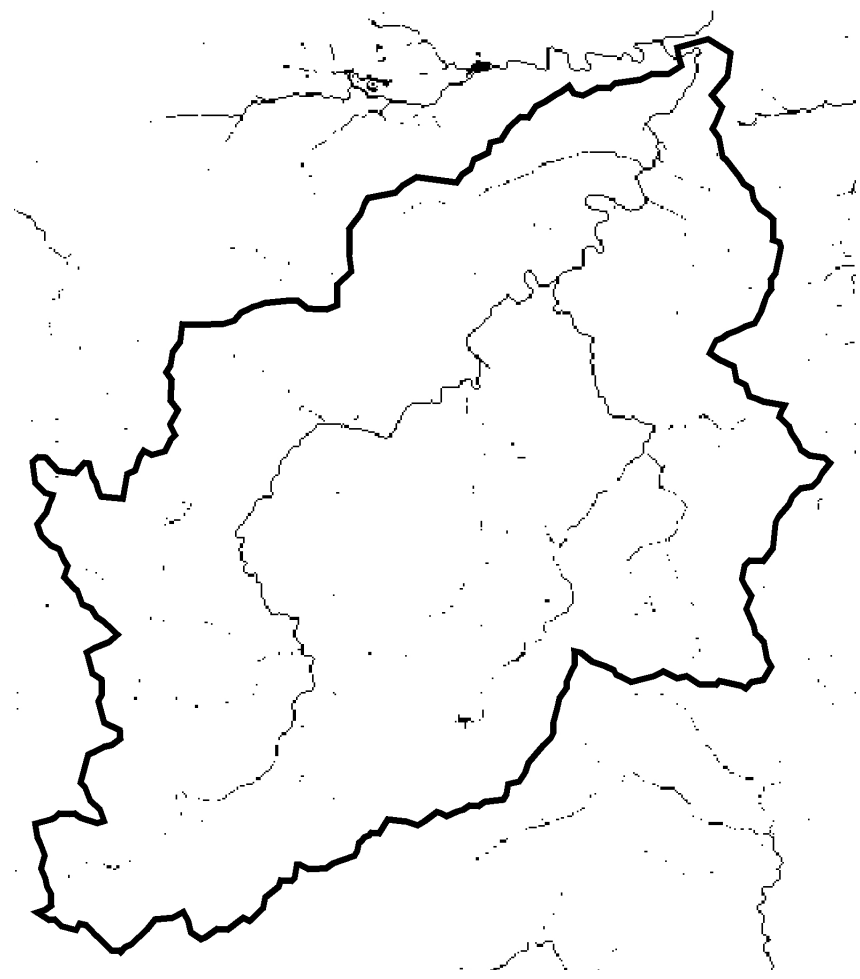

3, 3397-3438, 2006

\section{MARINE distributed model for flash flood modeling}

V. Estupina-Borrell et al.

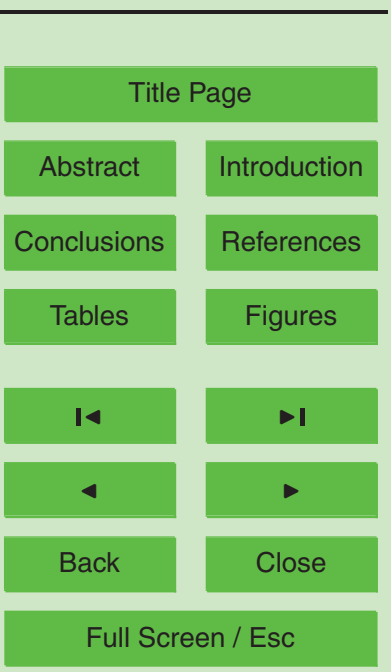

Fig. 12. Validity field of the cinematic wave approximation for the studied basin with a DEM pixel size of $50 \mathrm{~m}$ (black thick line: delineation of the basin, black fine points: excluded points

Printer-friendly Version from the field of validity, white area: field of validity of the cinematic wave approximation).

Interactive Discussion 


\section{HESSD}

3, 3397-3438, 2006

Floood hydrograph of the Orbieu river at Lagrasse Sensitivity of the initial water content of the soil (for a sandy clay loam soil) with the Green\&Ampt model

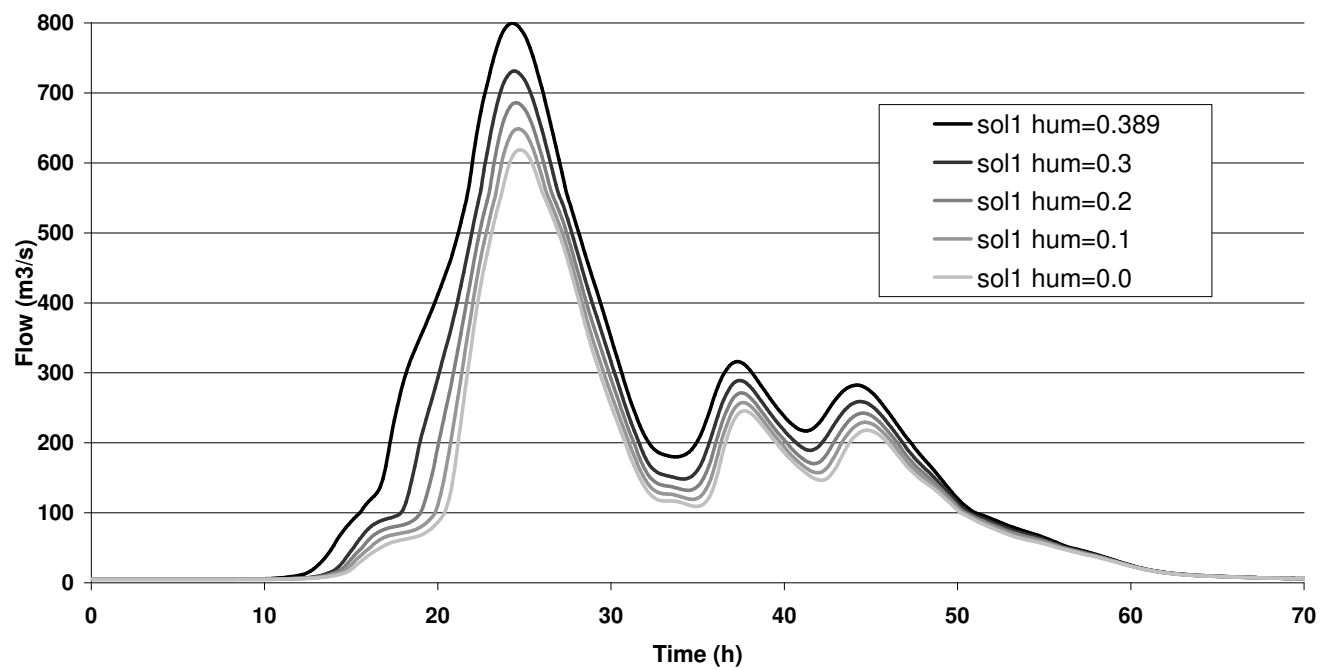

Fig. 13. Influence of the initial water content of the soil on a flash flood hydrograph with a Green and Ampt infiltration model.

\section{MARINE distributed model for flash flood modeling}

V. Estupina-Borrell et al.

\section{Title Page}

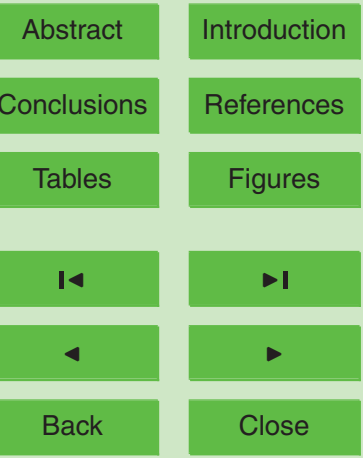

Full Screen / Esc

Printer-friendly Version

Interactive Discussion 


\section{HESSD}

3, 3397-3438, 2006

\section{MARINE distributed model for flash flood modeling}

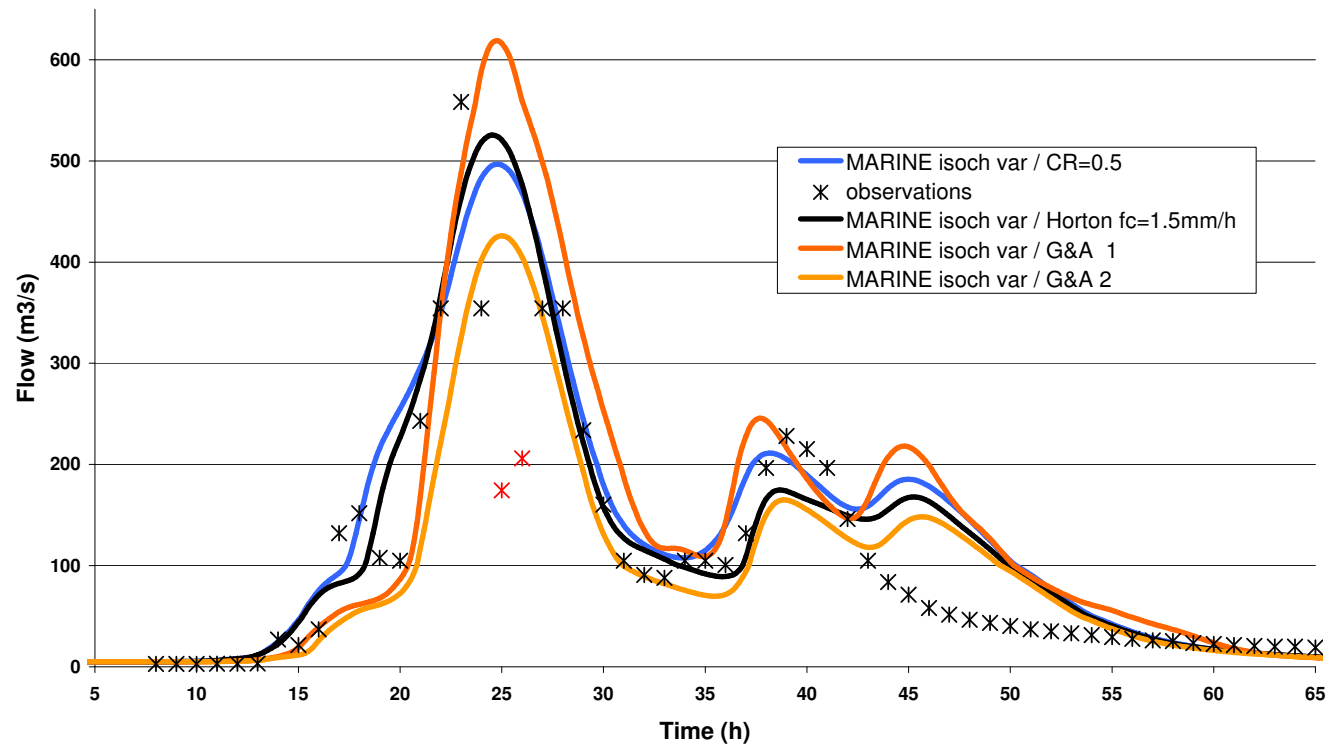

Fig. 14. Flood hydrographs at Lagrasse obtained with different infiltration modules of MARINE. 